\title{
Health + Equality + School Engagement: Scenarios USA reinvents sex education
}

Rafael Mazin

Andrea Lynch

Follow this and additional works at: https://knowledgecommons.popcouncil.org/departments_sbsr-pgy

Part of the Curriculum and Social Inquiry Commons, Educational Methods Commons, Educational Sociology Commons, Family, Life Course, and Society Commons, Gender and Sexuality Commons, and the Public Health Education and Promotion Commons How does access to this work benefit you? Let us know!

\section{Recommended Citation}

Mazin, Rafael and Andrea Lynch. 2014. "Health + Equality + School Engagement: Scenarios USA reinvents sex education," Quality/Calidad/Qualité no. 21. New York: Population Council. 
Health + Equality + School Engagement: Scenarios USA Reinvents Sex Education

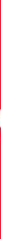


Quality/Calidad/Qualité, a publication of the Population Council, presents case studies of high-quality, innovative programs in sexual and reproductive health. $Q / C / Q$ specifically documents educational and clinicbased programs that are making strides in one or more of the following ways: (1) addressing the central importance of gender dynamics in shaping sexual and reproductive health outcomes; (2) improving the quality of care of clinic-based services; and (3) reaching disadvantaged and underserved groups. With rare exceptions, featured programs are operating in developing countries.

Q/C/Q case studies — selected by an expert advisory group-are offered not as models for replication, but as examples for learning. They demonstrate a responsiveness to broader social and economic transformations; they highlight inventive and affordable ways to respond to clients' needs; and they reflect the self-critical and flexible attitude required for learning from program experiences and research evidence. Although they are written as practical tools-in accessible style with carefully selected detail-they also serve to inspire program leaders and policymakers to enable clients to become more effective guardians of their sexual and reproductive health, and by doing so contribute fundamentally to the achievement of such broader aims as the Millennium Development Goals.

\section{Production Staff}

Editor: Deborah Rogow

Production Coordinator: Cecilia Choi

Copy Editor: Joyce Altman

Designer: Mike Vosika

Translation: Alpha Omega Translations

\section{Advisory Committee}

Gary Barker

Laura Laski

Carmen Barroso

Suellen Miller

Judith Bruce

Françoise Girard

Saumya Ramarao

Nicole Haberland
Ann Starrs

Cynthia Steele

\section{(2) Population Council}

Publication of this issue of Quality/Calidad/Qualité is made possible by support provided by the Ford Foundation and Scenarios USA. Statements made and views expressed in this publication are solely the responsibility of the authors and not of any organization providing support for $Q / C / Q$.

The Population Council conducts biomedical, social science, and public health research to deliver solutions that lead to more effective policies, programs, and technologies that improve lives around the world.

Population Council, One Dag Hammarskjold Plaza, New York, NY 10017 USA tel: (212) 339-0500 fax: (212) 755-6052 e-mail: qcq@popcouncil.org http://www.popcouncil.org

Cover: Texas contest winner Mariella Zavala (photo courtesy of Scenarios USA).

Any part of this publication may be copied or adapted to meet local needs without permission from the Population Council, provided that the parts copied are distributed free or at cost (not for profit) and that the source is identified. The Population Council would appreciate receiving a copy of any materials in which the text is used. 


\title{
Introduction
}

\author{
by Rafael Mazin
}

By signing the 1994 International Conference on Population and Development Programme of Action, the global community of nations has articulated and sustained a commitment to implementing sexuality education. ${ }^{1}$ It is generally known that these agreements call for education that promotes responsible sexual behavior and protects adolescents from early and unwanted pregnancy and sexually transmitted diseases. What is not always understood is that these agreements also explicitly call for such programs to address gender equality and equity, to promote the well-being of adolescents, and to protect adolescents against sexual abuse, incest, and violence (para. 35 [b]). Through delivering empowerment models of sexuality education, building young people's analytic skills, and ensuring safe learning environments, schools play a critical role in achieving these goals.

If presented in an adequate manner, sexuality education can help young people dispel myths and overcome shame and fears. Moreover, despite widespread fear and avoidance among many teachers, it is not particularly difficult to teach or learn this information. Nevertheless, "birds and bees" knowledge is not the core element of sexuality education; it is useless to treat young people as warehouses of "digested" knowledge. Sexuality education is meaningful only when it is humanized-when it is placed in the landscape of our everyday life.

The real challenge is to enable young people to connect knowledge about their bodies with their lived experiences and the world around them. This means teaching

Young people need opportunities

to reflect about their emotions,

analyze the power imbalances that

shape intimate relationships, and

develop competence to deal with

unequal social norms in a positive,

transformative way.

them to reflect about emotions (including desire, anxieties, and fears). It means helping them to analyze the power imbalances that so fundamentally shape intimate relationships and sexual risk and to develop the competence to deal with them in positive, transformative ways. Sexuality education must therefore focus on developing young people's analytic and critical thinking skills and fostering egalitarian and

\footnotetext{
1 These commitments have been reinforced by the Cairo+5 Agreement; the 2005 Protocol to the African Charter on Human and People's Rights on the Rights of Women in Africa (also known as the Maputo Protocol); and the Ministerial Declaration of Health and Education, 2008.
} 
respectful social norms, enabling them to apply newly acquired information in their own lives and in their intimate relationships. New evidence demonstrates that this empowerment approach is far more likely than conventional sex education to reduce adolescents' rates of STIs and unintended pregnancy (Haberland 2013). This-and nothing less-is what constitutes comprehensive sexuality education.

When a sexuality education program helps learners strengthen their higherorder thinking skills and face challenges in a creative, constructive manner, it is also contributing toward the achievement of overall learning standards and the creation of well-educated individuals. Such programs prepare students for active citizenship and help them overcome inequities and imbalances of power and transform their environment, rather than replicate the status quo.

Beyond the instructional process, schools are sites of socialization; they serve as spaces in which power imbalances may be perpetuated or transformed. Unfortunately, many school environments still tolerate (or even encourage) sexism; bullying, homophobia, and transphobia; and racism and xenophobia. Failing to address these issues does not reflect a policy vacuum; rather, it represents a tacit policy of condoning discriminatory practices and violence. In other words, whether by action or inaction, schools are already-at every moment-sending messages about gender, sexuality, and human rights to young people. For millions of young people, the Internet and popular culture are also important sources of information and messages about

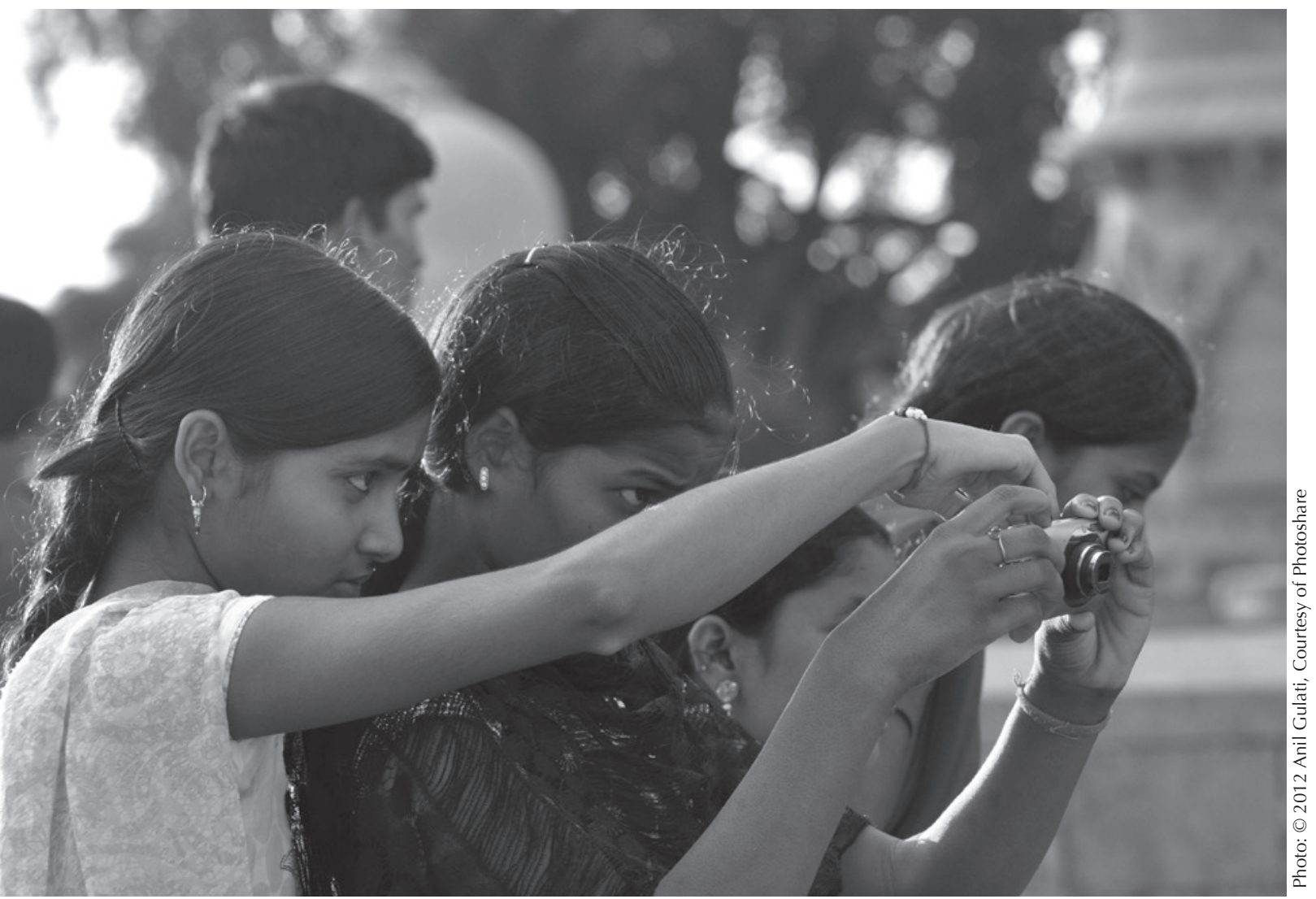

Programs around the world, like the one reaching these girls in India, empower young people to use photography, writing, theater, and other forms of self-expression to reflect on their lived experiences. 
these topics (Pascoe 2011). It is crucial to put policies and curricula in place for promoting gender equality and human rights across the school system; equally essential is ensuring that educators are positive role models. In recent years, education officials have begun to rise to this responsibility, setting both standards and an example for the learning community. Some countries have launched campaigns to end homophobia in schools, both as a matter of human rights and as an essential component of combating HIV and AIDS. The Pan American Health Organization (PAHO) is supporting these efforts. ${ }^{2}$ Such policy initiatives are promising.

Our concern should be focused on how to implement an empowerment approach. Technical resources offer guidance, but education leaders can also draw ideas and inspiration from models in the field. This issue of Quality/Calidad/Qualité highlights the experience of Scenarios USA, ${ }^{3}$ an innovative nonprofit program that has integrated a gender and rights perspective-and a critical thinking approach-into curricula, while fostering new pedagogies and greater awareness among teachers.

Scenarios USA approaches sexual health not as a standalone issue but as intertwined with young people's overall lives and agency. As such, the organization's "sex ed" work is part of a broader strategy of fostering self-expression, leadership, and advocacy among youth, especially among those living in marginalized communities. Instead of teaching adolescents about contraceptive methods, Scenarios has them thinking and writing about gender norms, power dynamics, and intimate relationships in their own lives.
Moreover, Scenarios gives young people's voices a permanent life. Whereas young people's voices are often fleeting, the organization sponsors a writing contest, selects winning stories, and translates them into powerful short films. These videos then become part of the next Scenarios curriculum, amplifying the message for hundreds of thousands of other young people.

Researchers are finding that this empowerment approach is far more likely than conventional sex education to reduce adolescents' rates of STIs and unintended pregnancy.

Scenarios is advancing the field toward what appears to be a far more promising approach-one that calls on us to depart from conventional approaches to sexuality education. The health, safety, and wellbeing of the next generation depend on our responding to the evidence and continuing to innovate.

\section{References}

Haberland, N. 2013. "What happens when programs emphasize gender? A review of the evaluation research." Presentation at Expert Group Meeting on Adolescent Sexual and Reproductive Health Programming. 4-6 February. Manhasset, NY.

Pascoe, C.J. 2011. "Resource and risk: Youth sexuality and new media use," Sexuality Research and Social Policy 8(1): 5-17. Published online: 12 March 2011.

2 For a copy of a recent fact sheet on addressing homophobia in schools, see http://coalicionmesoamericana.org/ node/20. For curriculum support on this topic, see: http://www.itsallone.org.

${ }^{3}$ EDITOR'S NOTE: In 24 years, this is the first time $Q / C / Q$ has published a case study from the United States, but the lessons from Scenarios USA are both exciting and manifold, and they touch on issues that are relevant in a wide range of settings around the world. 


\section{Health + Equality + School Engagement: Scenarios USA Reinvents Sex Education}

by Andrea Lynch

In 2001, Kristen Joiner and Maura Minsky were sitting on a bumpy school bus in Laredo, Texas, a city along the border of Mexico and the United States. The Scenarios USA cofounders had traveled to Texas with a film crew to shoot a short film about teen pregnancy based on an essay written by Samantha Hernandez, a 14-year-old Laredo student. The bus was filled with high school students who had volunteered to be extras in the film.

Suddenly, a teenage boy sitting across the aisle locked Maura's gaze. "Why do you care what we have to say?" he asked. "You're from New York. We're in South Texas. Nobody cares what we have to say."

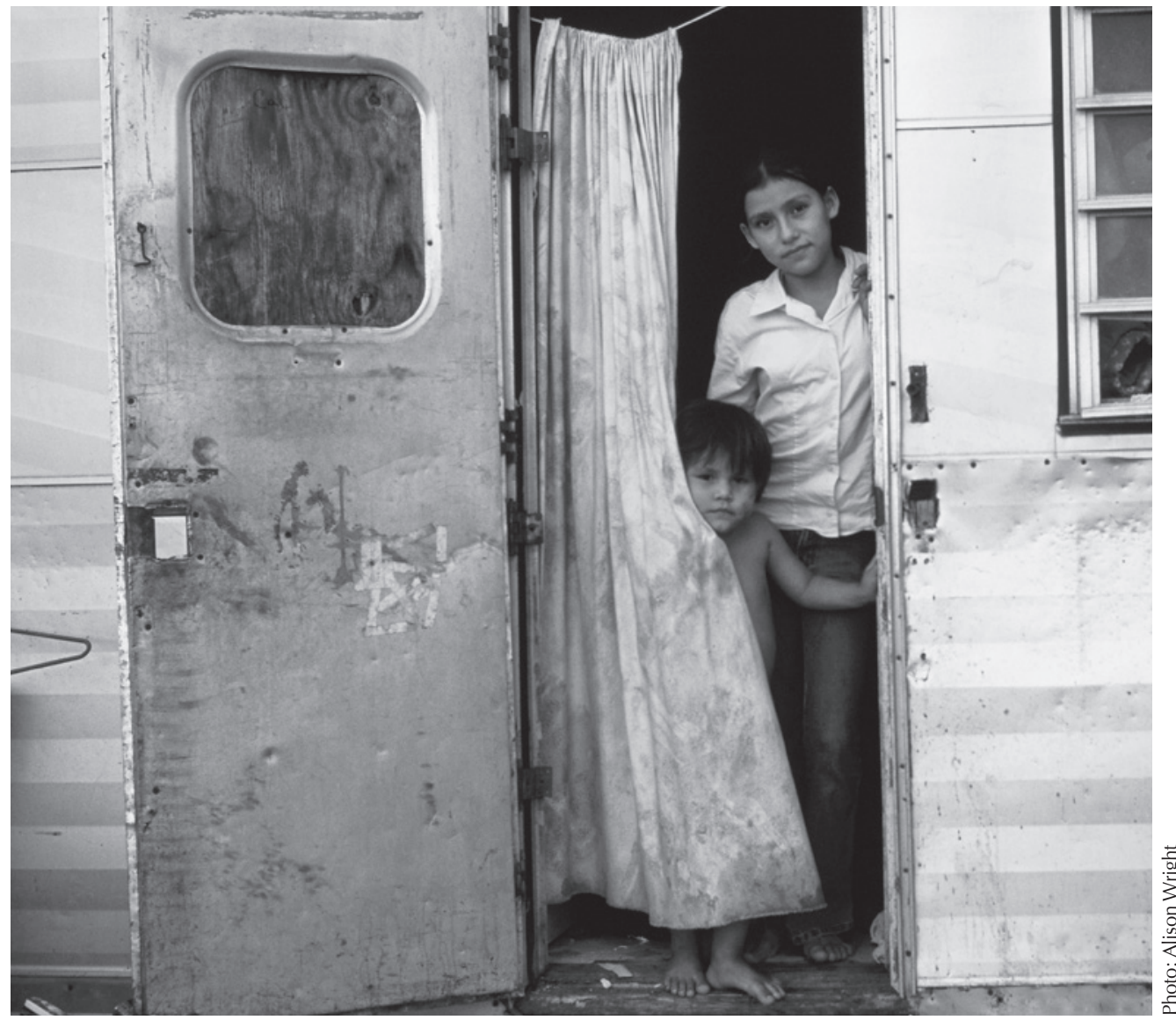

Scenarios USA began its work in the Rio Grande Valley, a region along the United States border with Mexico characterized by poverty. Adolescents in the Valley suffer high rates of unintended pregnancy and sexually transmitted infections. 


\section{Origins of Scenarios USA}

When Kristen Joiner and Maura Minsky met in New York City in 1998, Maura was a producer for a major television news station and Kristen was a program officer at a nongovernmental organization focused on international development. Although their professional backgrounds differed, they shared the desire to promote social justice through their work.

Kristen's job often took her overseas, and after one trip she called Maura to tell her about a West African project-Scenarios from the Sahel-that was addressing the HIV/AIDS epidemic through storytelling and film. The model was appealing: invite young people to submit stories for short films about HIV and AIDS, convene a committee of professionals to select the strongest "scenarios" submitted, and then pair the winning authors with African filmmak- ers to produce short films based on their ideas. The resulting films aired on television during the 1998 World Cup, raising awareness about how HIV and AIDS play out in daily life.

Both women were drawn to the idea of adapting the Sahel project for young people from marginalized communities in the United States. Maura had previously conducted interviews for the Shoah Foundation, which has recorded over 50,000 personal testimonies from Holocaust survivors, and she believed in telling stories that were relegated to the margins. For Kristen, the Sahel project evoked her experience as a community organizer in South Texas, near the border with Mexico. "I kept thinking about the teenagers there," she recalls. "If you got pregnant, you dropped out, that was it. I kept thinking about how great it would be to give them some tools to deal with that."

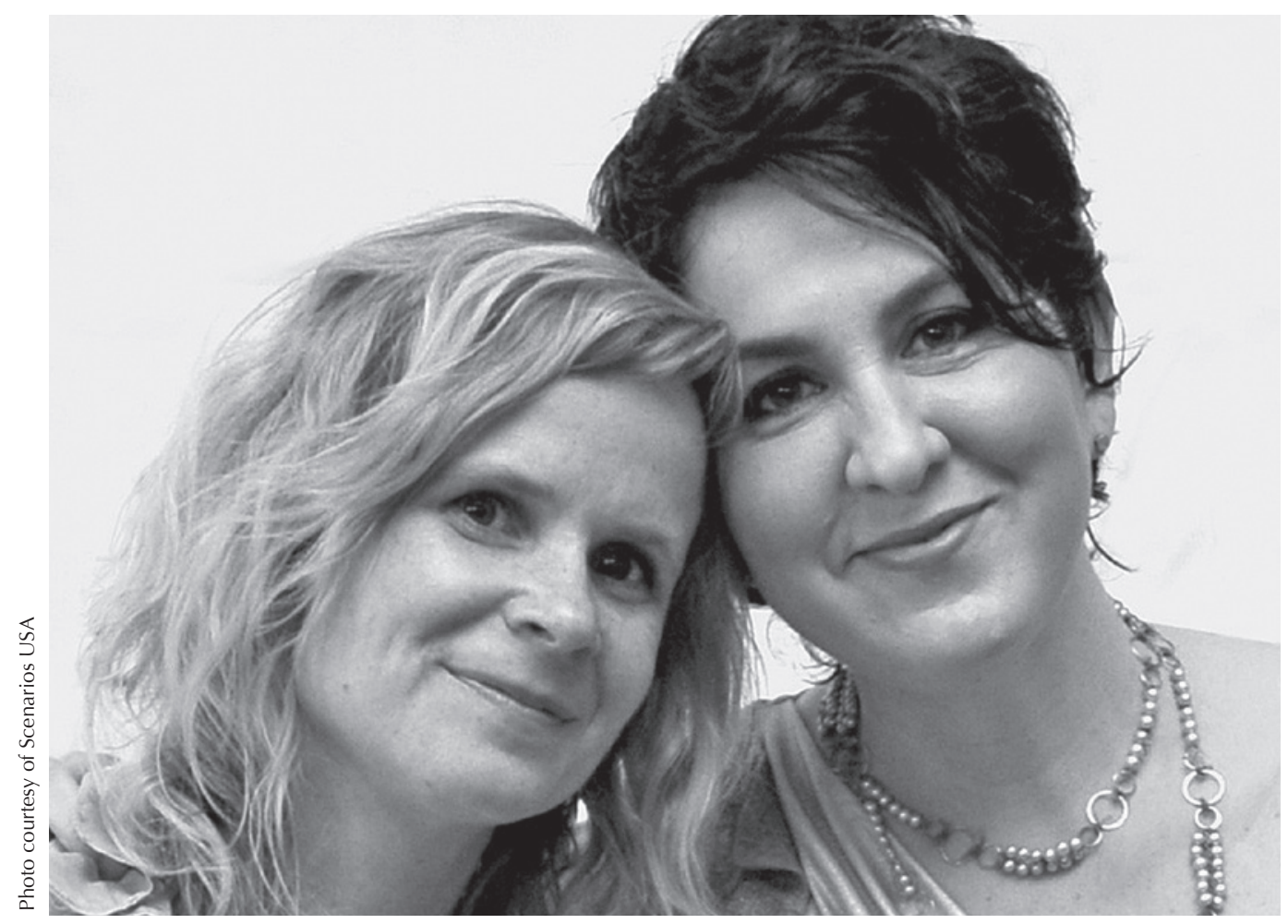

Kristen Joiner (left) and Maura Minsky, who cofounded Scenarios USA in 1999, codirected the program for over a decade. In 2007, Kristen moved from New York and took the helm at an environmental organization, remaining on the Scenarios Board of Directors. Maura continues as Scenarios' executive director. 


\section{Scenarios USA: An Overview}

Scenarios USA, ${ }^{4}$ a nonprofit organization based in New York City, has pioneered an innovative approach to sexuality education that is grounded in a gender perspective, critical thinking pedagogy, and storytelling. This approach represents a bold departure from conventional sex education. Instead of a narrow emphasis on reproductive health information and scripts for refusing sex, Scenarios focuses on the underlying social drivers of sexual experience and health. Specifically, Scenarios curricula challenge young people to reflect on, analyze, and write about gender norms, power, and relationships in their own lives.

Scenarios' vision reaches beyond sexual health. In fact, the organization's mission is a broad one: the fostering of youth leadership, advocacy, and self-expression, especially among young people from marginalized communities. Indeed, this wider lens is what enabled the organization to approach sexual behavior not as a standalone topic but as intertwined with young people's overall lives and agency. In doing so, Scenarios is leading the field toward what appears to be a far more promising approach, grounded in social and emotional learning.

Scenarios carries out its work through two interwoven programs. The education program creates curricula (and accompanying teacher-training workshops) on themes that underlie adolescent well-being and sexual health. The curricula, which draw on student voices and student-written short films, provide meaningful prompts for critical reflection and journal writing. At the end of each curriculum cycle, students adapt their writing into a fictionalized story, script, or other final project, which they have the option of submitting to a Scenarios-sponsored writing contest.

The film program amplifies student voices in a permanent way. Staff oversee the writing contest and then partner winning student-authors with professional Hollywood directors who volunteer their time. In consultation with Scenarios staff, each director-student team transforms the winning story or script into a high-quality, 15- to 20-minute film that is shot in the young writer's neighborhood or school, with significant youth and community participation. The resulting professional-grade short films are aired on television and at film festivals, distributed online, incorporated into future Scenarios curricula, and shown in classrooms across the country.

Scenarios actively involves young people in all of its work. Young people provide input for new curricula, serve as actors and interns on film sets, and in some cases advocate with their school districts to gain approval for controversial winning scripts. Scenarios also offers a more limited number of young people-particularly but not only those who win the writing contest-opportunities to build leadership skills and amplify their voices through arts, community organizing, higher education, and public speaking.

4 Scenarios USA takes its name from the project that inspired it: Scenarios from the Sahel, a West African initiative aimed at addressing the HIV/AIDS epidemic through storytelling and film, itself based on a French campaign called 3,000 Scenarios Against the Virus. Throughout this case study, we refer to Scenarios USA simply as "Scenarios." 


\section{Defining Principles}

Maura and Kristen founded their project on several interrelated principles, none of which derived from the sex education field.

\section{Listening to Young People}

One of the foundational principles of Scenarios was that young people would be given a platform in which to write and speak truthfully about their lives. Maura and Kristen saw young people as being experts about their own lives. This root in young people's voices is what makes Scenarios' work so "real" —and it is mentioned by students, teachers, and other allies as the distinguishing feature of the organization's work.

As a teen, as a human being, just having that opportunity to be heard, sometimes that's all students want. A lot of times being real-being really, really real-is frowned upon. You only do that when you're with your friends, right? But in Scenarios, students are rewarded for just being themselves and speaking the truth.

$$
\text { -Jermaine Wall, an early }
$$
writing-contest winner

\section{Emphasis on Personal Reflection and Narratives}

Maura and Kristen eschewed the conventional wisdom in the sex education field about focusing on a specific risk behavior, and they decided to abandon the typical sex education content. There would be no scientific information, no lectures on the risks of early or unsafe sex, no rehearsals of refusal scripts. Instead, they believed in the power of personal reflection and critical thinking about one's life and world as the pathway to change and better sexual health outcomes. They bet on journaling and storytelling as a way for young people to explore a range of emotions, experiences, and perspectives underpinning their identities, attitudes, and actions. Although their strategy was an intuitive one, evidence suggests that narrative writing can indeed have concrete health benefits. [See box, "Evidence on the Benefits of Using Narrative"].

\section{Commitment to Social Justice and Community Engagement}

From the start, Maura and Kristen wanted Scenarios to reach those young people whose voices were least likely to be sought and heard and who faced disproportionately high rates of HIV and teen pregnancy. In the United States, this meant working with young people of color who lived in socially and economically marginalized communities. They also wanted their work to promote more equitable relationships between boys and girls. Moreover, they saw collaboration with community members_in developing curricula, selecting winning scripts, and producing films-as a core strategy, and they wanted to stand

No scientific information, lectures on

unsafe sex, or rehearsing "refusal"

scripts-the Scenarios model gives

students voice. As former student

Jermaine Wall explains, "Just having

that opportunity to be heard, some-

times that's all students want."

by young people who engaged their own communities about the issues they were writing about.

Finally, because Maura and Kristen were remarkably open to learning and willing to change course, Scenarios has continually evolved and has maintained stable leadership. (Kristen left her position in 2007 to lead an environmental organization but remains on the Board of Directors; Maura continues as executive director.) 


\section{Evidence on the Benefits of Using Narrative}

Narrative and storytelling play a central role in Scenarios' programs. Students discuss the films they watch, keep journals, and develop their writing into scripts. The curriculum also trains students in storytelling. Research suggests that such narrative expression can lead to positive outcomes (Pennebaker 1997; Pennebaker and Seagal 1999; Campbell and Pennebaker 2003). In one study, students who wrote about emotional topics had more improvements in grades and fewer illness-related visits to the health center compared with those in a control group; evidence of the direct effect on stress is mixed.

Casemore, Sandlos, and Gilbert (2011) argue that a narrative rather than a knowledge-based approach-what they call "an interpretive rather than an instrumental orientation" - is particularly important for sex education, to allow young people to link what they learn in class with their complicated experiences outside the classroom. Sandlos (2010: 301) similarly critiques knowledge-based approaches to sex education, arguing that rather than filling any real gap in understanding, they function as a defense against thinking about emotional reality. She argues instead for providing young people with opportunities to address their "worries, desires, and internal conflicts."

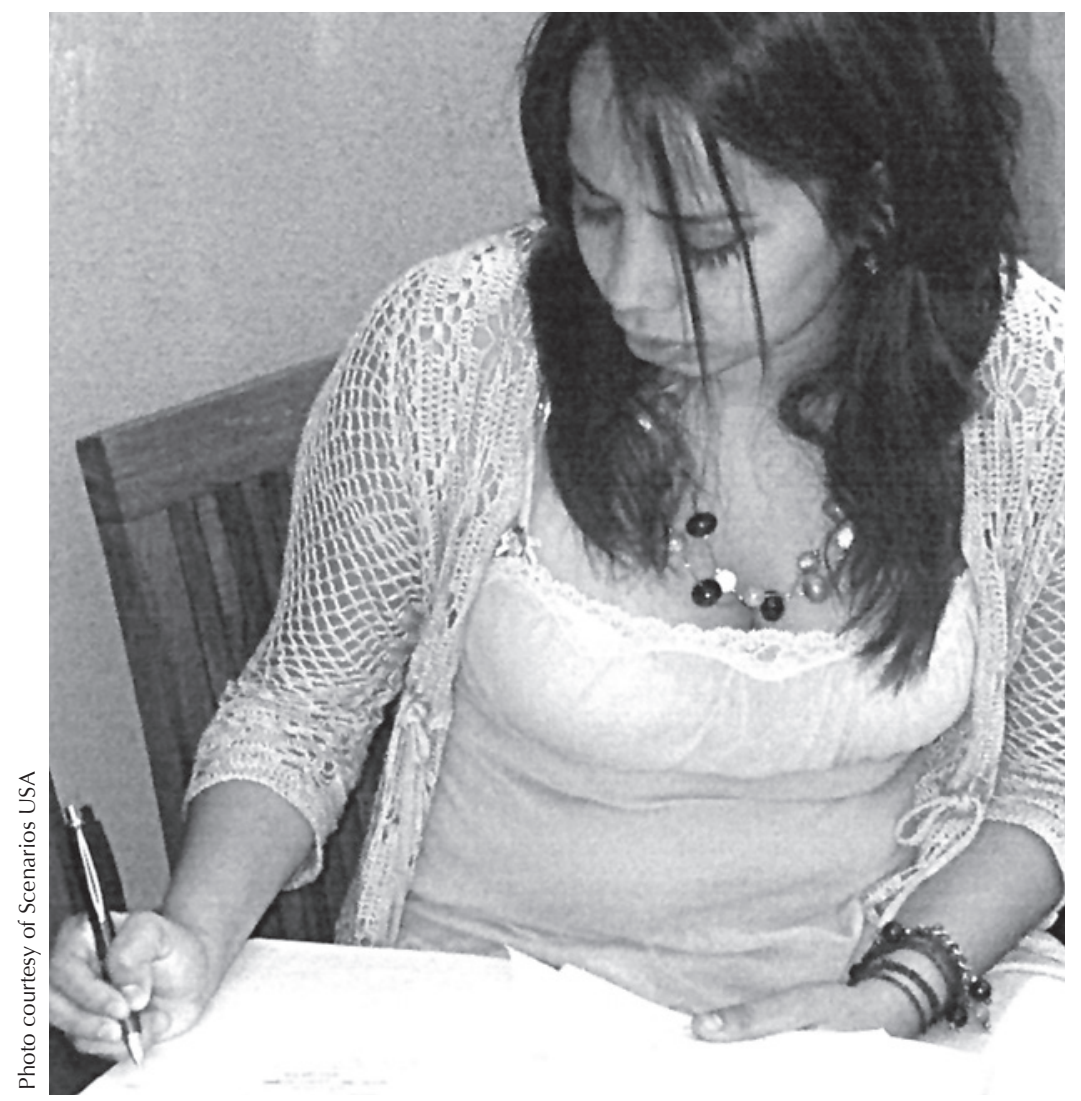




\section{Launching the Organization}

Maura and Kristen placed a strong value on collaborative leadership. Their first step was to meet with a wide range of organizations in New York City to get input as to whether their proposed initiative was needed, and if so, how it might best be structured. They drew from these conversations, and from a replication guide provided by Scenarios from the Sahel in carrying out the following planning steps:

- Canvassing additional stakeholders and experts: To gauge interest and gather advice, Maura and Kristen consulted local youth-serving organizations, HIV/AIDS prevention groups, school administrators, public health professionals, and teachers.

- Choosing a delivery model: The decision was made to work with public school systems. This choice entailed a host of practical and political challenges but would reach the greatest number of young people and hopefully spark deeper institutional change.

- Defining a geographic audience: To begin, they settled on New York City (where they both lived) and South Texas, where Kristen had worked as an organizer. In both areas, the schools were reaching young people living in marginalized communities and facing disproportionately high rates of HIV and unintended pregnancy.

- Designing program content: In partnership with teachers, Maura and Kristen at first developed a series of "prompts" on HIV/AIDS, pregnancy, and sex to spark classroom conversations and writing exercises. (This later evolved into a full curriculum.)

- Finding partners and allies: Maura and Kristen identified enthusiastic teachers from high schools in New York and South Texas to pilot the program and facilitate submission of students' scripts on a fixed deadline. To produce the first films affordably, Maura and Kristin found individuals in the film community who were willing to loan equipment, donate time, or work at a reduced rate. They also recruited a diverse group of young people and adults to serve on the Script Selection Committee.

- Seeking funding: Maura and Kristen volunteered their time at the start, but in 2000 they secured initial funding of $\$ 30,000$ (from the William T. Grant Foundation, the William and Flora Hewlett Foundation, the Colin Higgins Foundation, and the Sonya Staff Foundation) to produce the first two films.

For the entire first year, Kristen and Maura volunteered, Kristen on a full-time basis. The pilot went well. Given the sparse funding, the two films were short-less than four minutes apiece. Each was shot in a single day-one in New York City and one in Pharr, a small Texas town near the Mexican border. Both

\section{The decision to work with public} school systems entailed challenges. In working through these challenges, Scenarios also sparked institutional change.

were enthusiastically received during local screenings and at a New York City premiere organized by Scenarios. The films aired on MTV and at film festivals, and were adapted into teaching tools for use in classrooms across the country. Copies were also sold to generate income for the organization.

Then the next cycle began. Another set of discussion prompts resulted in two more films and a second, more substantial, grant from the Hewlett Foundation in 2001. These funds, together with the funds generated by sales of the first four films, provided for two salaries. Maura left her job and she and Kristen became full-time paid staff at Scenarios. 


\section{Education Program: The REAL DEAL Educational Cycle}

The basic model for Scenarios' education program has remained constant. Every two years, the staff-in partnership with educators and experts-produces a new curriculum and organizes teacher-training workshops in areas where formal partnerships have been established with the school districts. (Over the years, focus areas have included Chicago, Cleveland, Miami, New York City, and the Rio Grande Valley in South Texas.) Although the formative principles have not changed, the focus has continually evolved, from a narrow emphasis on outcomes to the intersection of underlying factors that influence young people's attitudes and decisions.

\section{Engaging young people in critical}

\section{thinking about gender norms has}

wider potential benefits-reducing

intimate partner violence,

strengthening critical thinking

skills, and fostering students'

engagement with school.

\section{Sensing the Limits of \\ "Comprehensive Sex Ed"}

Even as the program grew, gaps began to surface in the so-called "comprehensive sex education" model. Kristen recalls, "It just wasn't clicking. I remember a conversation with a student named Nicole who said, 'I just don't understand how people make decisions about sex. I just don't understand.'"

Nicole's comment crystallized an underlying tension that had been becoming more apparent to Maura and Kristen as they read young people's submissions to the REAL DEAL writing contest and spent time in their schools and communities. They realized that accurate information and sexual refusal scripts are a tiny slice of what young people need to take control over their sexual and reproductive lives. A far thornier obstacle was what Maura and Kristen began to refer to as the "social context" of adolescent decisionmaking: that is, the degree to which circumstances, social and cultural norms, and daily socioeconomic and interpersonal struggles shaped young people's decisions and futures. Maura recalled one girl who had won the writing contest and was pregnant when she came to the premiere of her film. Maura explains what she learned about the underlying circumstances:

It turns out that this girl had been kicked out of her house. She went to live with her boyfriend and he wouldn't use a condom. So her becoming pregnant wasn't a question of not knowing the facts. It didn't fit stereotypical notions of why young people get pregnant by accident. It was actually a question of safety and housing.

A 2004 content analysis of more than 400 submitted scripts documented that the students were still falling back on conventional social norms in their stories (MuñozLaboy et al. 2004). Their scripts typically reinforced fear-based and moralistic messages about sexuality and sexual health. 
Too often they also reinforced double standards about sexual behavior, and reinforced rather than questioned conventional gender norms and roles. Kristen and Maura realized that to help students examine the underlying social context driving their health outcomes, they needed to make further changes, and reframe their questions, focus, and pedagogic approach.

\section{"Oh ... This Is What's Going On"}

About the time they were pondering the limits of the "comprehensive sex education" model, Maura and Kristen attended a Population Council presentation about the Rethinking Sexuality Education (RSE) project. Council staff demonstrated the profound degree to which adolescent sexual health is shaped by gender norms and by disproportionate power in intimate relationships. [See box, "Gender Norms and Relationship Power Drive Sexual Health Outcomes."] Based on this evidence, Council researchers advocated for a paradigm shift in sex education-toward a social studies approach emphasizing re- flection and critical thinking about gender issues (including the way gender interacts with other aspects of social context, such as class and race).

For Maura and Kristen, this was a revelation. They understood the connection but were uncertain about how to fully integrate this approach at a deep level.

Kristen would ask, "What if the boy does want to have a real relationship? Boys are so emotionally connective in their early years, and then it's bashed out of them. And girls feel desire, why is it taboo? What is going on?"

Then we encountered the Population Council, and suddenly it was, "Oh, this is what's going on."

As Maura reflects, "The questions that we had were about gender norms, but we didn't know that." This evidence crystallized for Maura and Kristen how Scenarios should move forward. They now had a theoretical framework and a new set of terms that clearly articulated what they were already trying to do.

\section{Gender Norms and Relationship Power Drive Sexual Health Outcomes}

Studies around the world show that young people who, compared with their peers, adhere to more conservative gender norms or form relationships characterized by disproportionate male power, are less likely to use condoms and contraceptives and more likely to experience unintended pregnancy and sexually transmitted infections (STIs), including HIV; their relationships are also more likely to be characterized by gender-based violence (Rogow and Haberland 2005: 333). Recent evidence suggests that an approach to sex education that sparks reflection on traditional gender norms and power in intimate relationships is far more effective than conventional "comprehensive sex education" at reducing unintended pregnancy and STIs (Haberland 2013). Moreover, engaging young people in critical thinking about gender norms has wider potential benefits-reducing intimate partner violence, strengthening critical thinking skills, and fostering students' engagement with school (see Introduction, page 1). 


\section{Innovating in Curriculum Development}

As Scenarios grew increasingly aware of how deeply young people's sexual health is anchored in their social context, they grew committed to rehauling their pedagogic approach, and Maura and Kristen decided to invest in developing a formal curriculum. In their search for a more effective approach, they met Ernestine Heldring, a former social studies/humanities teacher in the International Baccalaureate (IB) system. The IB's approach to critical thinking and inquiry-based learning seemed to represent the perfect framework for educating teenagers to think differently about gender norms and meet learning standards. Scenarios hired Ernestine to write a new curriculum using the IB method. (Originally hired as a consultant, Ernestine joined the staff in 2008 and until recently served as Director of Education.) Ernestine explains the challenge she took on: "Traditional teen pregnancy prevention curricula already existed. What was missing was an in-depth look at what shapes teen attitudes toward sex, love, and relationships, and where that comes from."

The new curriculum was called "What's the REAL DEAL about Romance and Re-



As Director of Education, Ernestine Heldring helped Scenarios formalize the curricula, emphasizing critical thinking and inquiry-based learning. lationships?" The goal was not to transfer information about sexually transmitted infections or condoms, or to reach consensus on the negative consequences of early pregnancy. Rather, it was to build students' capacity for reflection and analysis and to cultivate a classroom environment that enabled young people to express themselves, listen to each other, learn from each other, and disagree respectfully. The Romance and Relationships curriculum also began to place greater emphasis on positive portrayals of intimate relationships between teens.

Ernestine consulted with teachers, young people, and experts in adolescent health and other fields during the development and field-testing phase. The final product established the basic template for all of Scenarios' future curricula-a series of 50-minute lessons with the following characteristics:

- Standards-based: Originally linked to standards for individual state Departments of Education, the curricula now align with the Common Core State Standards being adopted across the US.

- Adaptable: Usable in language arts, social studies, and theater classes in the US, and for students of all abilities.

- Multimedia: Packaged with student films produced during previous Scenarios contest cycles, with lessons based on the films.

- Inquiry-based: Fostering analytic thinking, social/emotional learning, and problem solving, via discussion and writing.

- Pedagogically detailed: Including openended guiding questions, discussion guides, tips for teachers, and suggestions for assessing work.

- Writing-focused: Offering practical information on how to write scripts (the culmination of each curriculum). Curriculum includes writing journals that are distributed to each student. 
Ernestine's approach also helped Scenarios sidestep common challenges faced by sex education advocates. First, the new curriculum linked the lessons to specific established learning standards. This allowed teachers and principals to see the curriculum as helping to fulfill established goals and contribute to overall education, rather than compete with academic objectives. Michelle DeFranco, an English teacher in the Bronx (New York City) at Hostos Lincoln Academy, comments:

\begin{abstract}
As an English teacher, I stress plot development, character arcs, making sure the story has a beginning, middle, and end. The hope is that my students are learning about all of that good stuff without really realizing it. Sex is just the theme.
\end{abstract}

This repositioning was particularly critical because school systems were experiencing a shift toward standards- and test-driven outcomes that constrained teachers' ability to teach content not directly linked to state standards.

Second, the new curriculum reduced the risk of political opposition. Because the content had shifted from sexual health to a broader interdisciplinary rubric (romance and relationships), the curriculum could "fly under the radar" in conservative states. This was important in Texas, where the acceptance of restrictive federal funds for "abstinence only" programs had made it difficult to teach sex education. "We couldn't take our first film into the Texas schools," explains Rob York, Scenarios' Director of Media Production and Distribution. "We wouldn't be welcomed in by the principal, or the vicar, or the school district officials. But we were able to bring this program into all of those places." The Romance and Relationships curriculum was endorsed by principals, picked up by teachers, and received with enthusiasm.

\section{"What's the REAL DEAL about Masculinity?"}

Despite the progress made with the Romance and Relationships curriculum, staff remained concerned that students were still not thinking critically enough about the stereotypes and presumptions that influenced their decisions. For example, the submitted scripts still tended to reinforce traditional gender norms. Maura and Kristen decided to ask those leading the Population Council's Rethinking Sexuality Education project for help building their capacity in the area of gender, both for curriculum development and for evaluation. The next curriculum represented a breakthrough. For the first time, the curriculum was structured explicitly around gender issues-it was called "What's the REAL DEAL about Masculinity?" The aim was for students to deepen their understanding of the issue and to question prevailing norms that they had taken for granted. The masculinity curriculum centered on seven comprehensive lessons:

1. Introduction to story, play, and scriptwriting

2. Introduction to the topic of masculinity

3. Strength and violence

4. Sexuality and intimate relationships

5. Being a father

6. Masculinity in the media

7. Consolidating student writing and fact-checking

Along with the curriculum, teachers received a set of pocket-sized blank student journals, a DVD of Scenarios films, instructions for students to enter the writing contest, guidance on how to use the materials effectively, sample worksheets, a list of hotlines and local organizations focused on violence and sexual health, and a list of learning standards that the curriculum helps meet. 
The topic of masculinity hit a nerve with teachers and students alike. The response was very strong and the organization made another leap toward the kind of work it felt was needed. For example, one teacher described his students' reaction to Life's Poison, a Scenarios film about a boy who has shut down emotionally, both as part of male socialization and in response to violence at home:

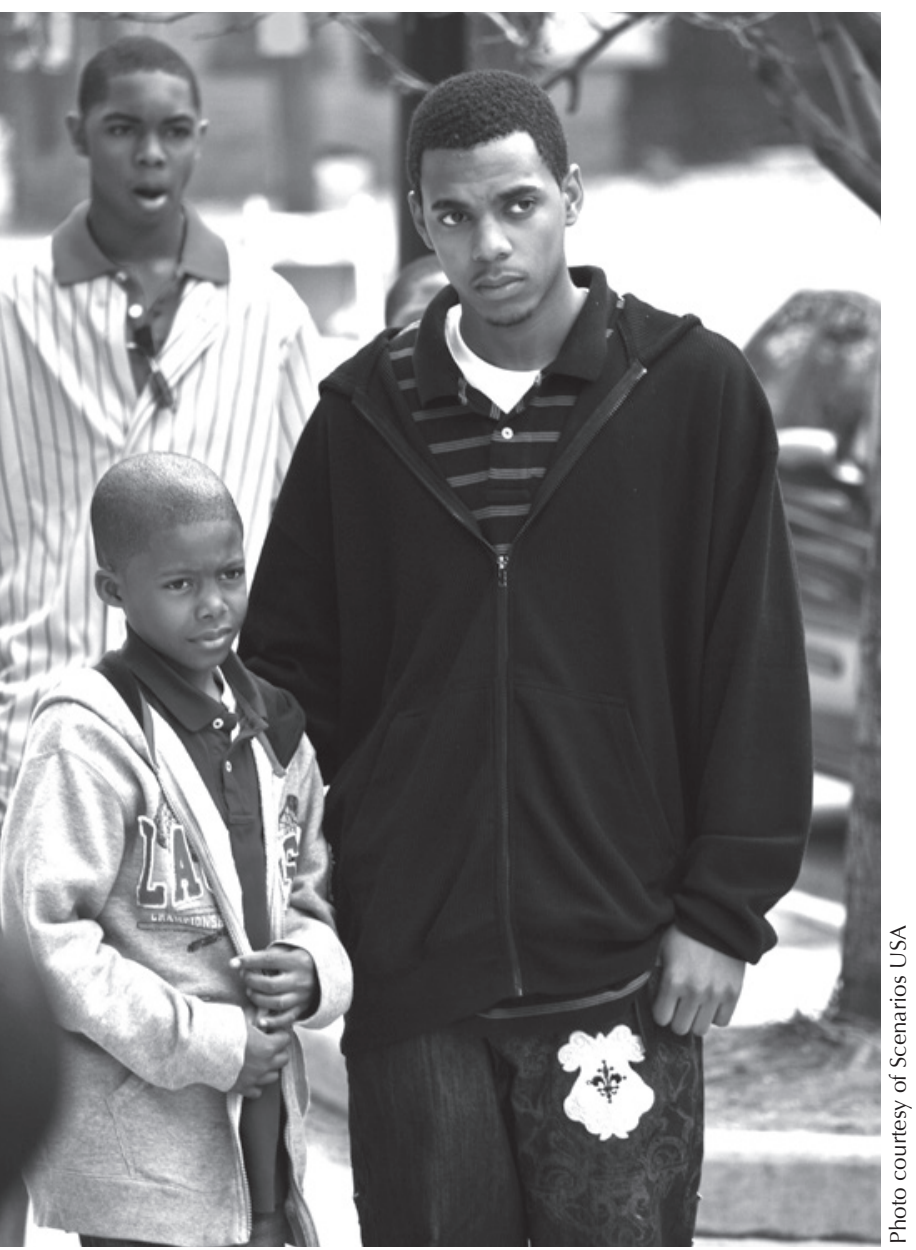

In Cleveland, almost four-fifths of the students did not have a father at home; many teachers also described complicated feelings about their own fathers. The "Masculinity" curriculum, and particularly the lesson about fatherhood, hit a nerve.
It speaks to youth, to every single one of them. There were certain points where the kids were really quiet, where some of the boys would look down at their laps. Everyone would notice, nudge each other. They knew that it was because it was ringing true. When some kids would make "smart" comments, others would say, "Shhh! I want to watch this."

A content analysis that compared scripts submitted after this curriculum with those from previous cycles of submissions showed much deeper questioning of conventional gender norms. When the new films were completed, Scenarios substituted them into a slightly revised curriculum and sponsored a second "What's the REAL DEAL about Masculinity" cycle.

The revised masculinity curriculum also reflected other lessons from process evaluation. For example, the unit on fatherhood was emotionally powerful but often discouraging. In Cleveland, almost four-fifths of the students did not have a father at home, and many of the teachers themselves had complicated feelings about their own fathers. To avoid ending on a depressing note, the unit on fatherhood was shifted to an earlier point in the curriculum. Another finding was that the lesson plans needed to focus more attention on how students' experience of gender was conditioned by other dimensions of their social context-most crucially, their race, class, and sexual orientation.

A 2009 evaluation demonstrated that the masculinity curriculum effected change in three areas: students' attitudes about gender (particularly masculinity); their demonstrated skills in critical thinking and dialogue; and their engagement with school and the strength of the connection to their teacher. ${ }^{5}$ (For more detail on this evaluation, see Assessing Outcomes, page 27.)

\footnotetext{
5 This last outcome is itself vitally important. A review by the CDC (2009: 5) found that school connectedness was "the strongest protective factor for both boys and girls to decrease substance use, school absenteeism, early sexual initiation, violence, and risk of unintentional injury."
} 


\section{Thinking and Writing Critically}

Developing more egalitarian attitudes toward gender (a pathway to better sexual health outcomes) requires personal reflection and critical thinking. Hence, the explicit thematic focus on masculinity proved synergistic with the inquiry-driven pedagogic approach Ernestine was advocating, and it allowed Scenarios to explore a broader range of strategies for sparking critical analysis and discussion. For example:

- To foster sustained discussion, each unit begins with broad, open-ended "essential questions": Who am I? Where am I going? Who do I want to be?

- To encourage engagement, reflection, and higher-order thinking, the curriculum is also learner-centered, with the teacher encouraged to act as a facilitator rather than an instructor.

- Activities incorporate group work and diverse teaching methods (not only plays and discussion, but collaborative art and research projects) that keep large classes engaged. Since 2011, Scenarios has also integrated social media activities (for example, involving Facebook and/or YouTube in lessons).

Indeed, research has suggested that this type of "open classroom climate," particularly when combined with increased media exposure, can have a transformative effect on students' attitudes toward citizenship and their support for gender equality (Pettersson 2003).

Students also keep personal journals, which help them link abstract concepts with their own lived experiences and per- sonal opinions. Ernestine anticipated that journaling would help keep girls engaged on the topic of masculinity, even if the boys did not find the journals appealing. She comments that the students disproved her assumptions: girls were extremely interested in the topic and most boys loved

Some boys reported that

writing in their journals

helped them process difficult

experiences and organize

their thoughts, which

empowered them to participate more in class discussions.

journaling. Several boys reported that writing in their journals helped them process difficult experiences and organize their thoughts, which empowered them to participate more in class discussions (ElHinnawy 2009), and quite a few boys continued journaling after the curriculum was completed. Journaling has remained a mainstay of the curriculum.

Scenarios staff acknowledge that they also engage students by way of incentive. The curriculum culminates in a writing contest, and the prize involves working with a Hollywood director to make a film similar to the ones they see during the curriculum. ${ }^{6}$ Especially for students who tend to be unengaged in school, this incentive "hooks" them into investing their emotional, intellectual, and creative energy in the curriculum and their writing.

\footnotetext{
6 The writing contest (leading to film production) takes place in the regions where Scenarios has established partnerships. However, the curriculum and accompanying films are used in many other settings, where instructors organize alternative incentive projects, such as the publication of final stories, theatrical productions, or individual PowerPoint presentations.
} 
"What's the REAL DEAL about Gender, Power, and Relationships?"

The next Scenarios curriculum was a direct outgrowth of the lessons from the evaluation of the "What's the REAL DEAL about Masculinity" curriculum? (see page 13). Scenarios wanted to ensure that the next curriculum would better reflect how multiple dimensions of identity (including race and class, for example) inform young people's sense of agency and their sexual and social decision-making. They also wanted the curriculum to end on an aspirational, resilient note. Ernestine explains that these two lessons from the evaluation were actually interrelated, saying, "We're talking about oppression, marginalized people, LGBTQ youth. They might not be in a situation where there's a lot of fabulous stuff going on in their lives right now, so the last lesson has to be empowering and look forward."

In 2011, Scenarios debuted "What's the REAL DEAL about Gender, Power and Relationships?" Along with new activities that help students analyze how power operates in all relationships in their lives (personal to societal), this curriculum ends by asking young people to write letters to their future selves, focusing on hopeful goals for their future lives and relationships.

Teacher Michelle DeFranco affirms that this thematic frame has facilitated even deeper critical thinking among her students:

It makes kids more socially conscious and aware. I like the topic this yeargender, power, and relationships. It helps students think critically about the interplay between these three things. Some complain that it's hard. But recently, one said, "Oh, I was talking about that to my mother on the bus, and this man just chimed in and talked about women in his society." This is great! They're talking about issues to their mother on the bus and some stranger chimes in!

Another 2011-12 curriculum innovation was the integration of activities in which students use Facebook, YouTube, and other social media.

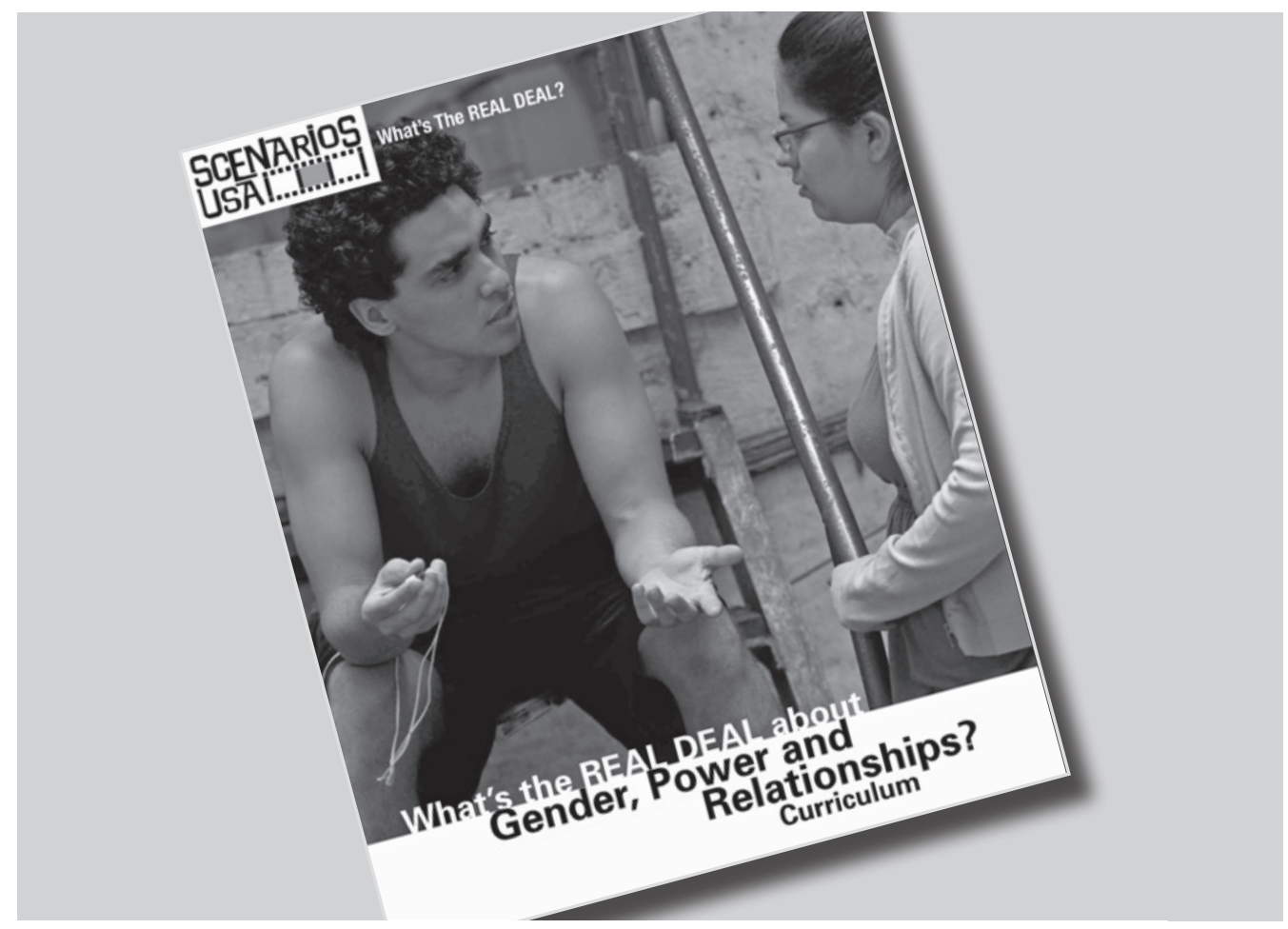




\section{Teacher Support and the Learning Environment}

For the most part, Scenarios distributes its curricula and films as standalone products. ${ }^{7}$ However, the organization has formal partnerships in three regions where it works closely with the local school districts and other stakeholders. To carry out this work, Scenarios added field organizers in each of these regions: Kathleen Hayes in Chicago, Stephanie Wahome in Cleveland, and Melinda Evans in New York City. ${ }^{8}$
A key element of these partnerships is teacher-training. At the start of each school year, partnering school districts notify teachers about the Scenarios workshop (cofacilitated by Scenarios staff and a local teacher or partner organization). At the workshop, teachers learn how to deliver the curriculum and facilitate students' participation in the creation of the final project, about the importance of narrative writing and the journal, and about kinesthetic and other interactive activities from

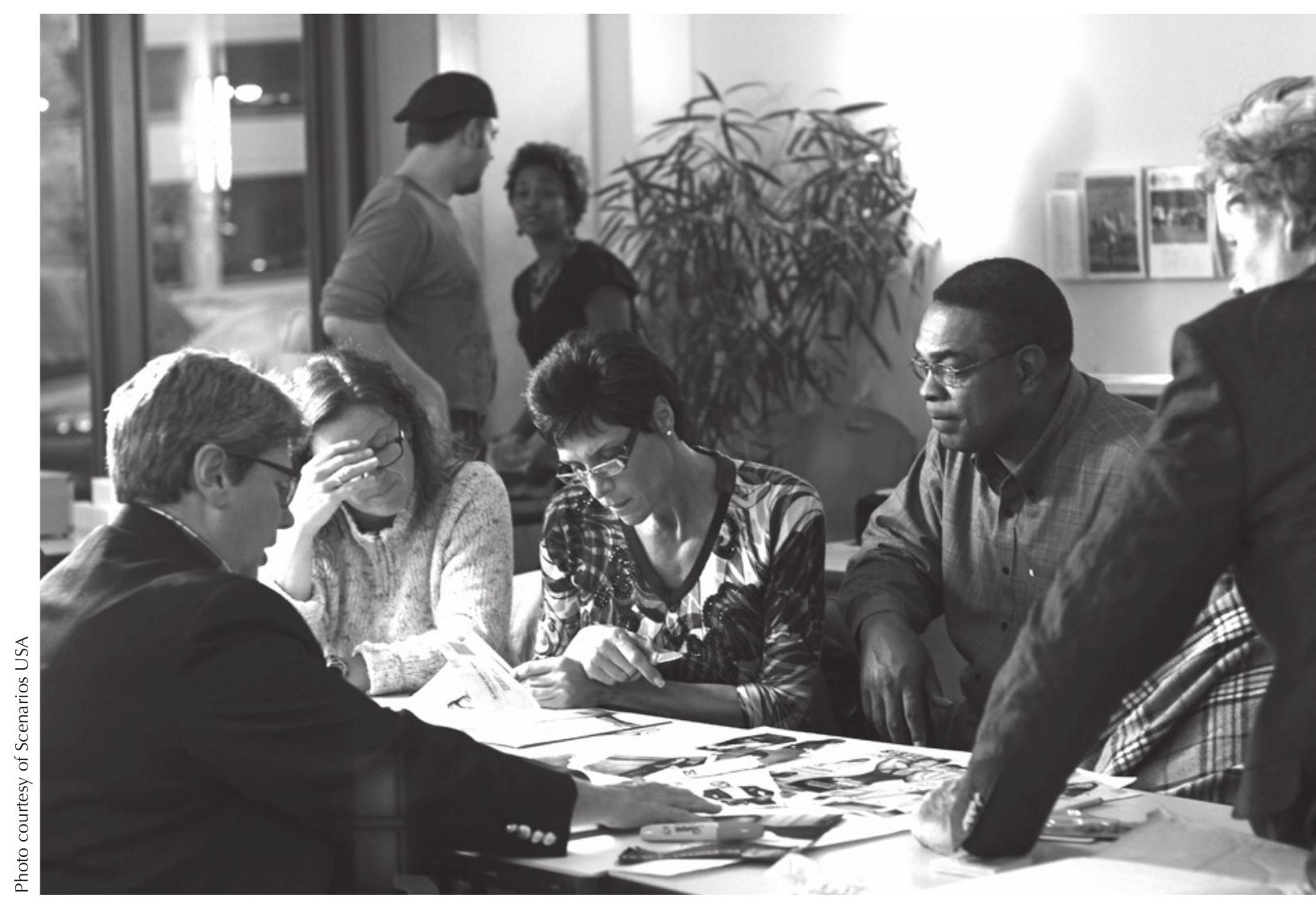

Some teachers report that teaching the Scenarios curricula has transformed their practice. Many continue to teach the curricula over years, returning for training each time Scenarios develops a new curriculum.

7 Ordering information is available on page 37.

${ }^{8}$ As this issue of QCQ went to press, Ernestine Heldring was returning to classroom teaching and graduate studies; Melinda Evans was replacing her as Scenarios' Director of Education. 
the curriculum. In all these ways, Scenarios and its community partners help teachers develop more comfort with the curriculum topic and with participatory or innovative methodologies they may not have used in the past.

The training also emphasizes key principles for creating an effective learning environment:

\section{Building Student-Teacher Trust}

A student's sense of connectedness to teachers is a major factor in his or her engagement and success at school (Barber and Olsen 1997; Rosenfeld, Richman, and Bowen 1998; Battin-Pearson et al. 2000; Klem and Connell 2004; CDC 2009). This trust is particularly salient with regard to

\section{A student's sense of connectedness}

to teachers is a major factor in

his or her engagement and success

at school. This trust is particularly

salient with regard to such

personal matters as sexuality

and relationships.

such personal matters as sexuality and relationships. As Ernestine observes, "Our idea is to bring young people's whole selves into the classroom, and the teachers' role is critical. It's that emotional connection. It's the teacher and the students doing the work."

\section{Creating a Safe and Supportive Classroom}

The workshops emphasize the importance of establishing and honoring ground rules during class discussions, respecting the confidentiality of young people's journals, treating journal entries as fictional accounts, ${ }^{9}$ and enlisting the support of guidance counselors or other youth service professionals when necessary. Teachers are encouraged to inform students about hotlines (provided in the curriculum) and to familiarize themselves with locally mandated reporting requirements, in case a student discloses abuse.

Scenarios also provides ongoing support to teachers. By way of a monthly "Curriculum Corner" newsletter, webinars, an educator blog, classroom visits, and informal contact, the staff learn how the curriculum is being taught and seek opportunities to gather and respond to teacher feedback. Michelle DeFranco, who has been teaching the REAL DEAL curricula year after year, comments about the benefits of partnering with Scenarios:

It's made me a better teacher. I learned that [my] role is really as a facilitatornot to pontificate, but to let the kids discover what they know and let them flourish. It helped me create an environment in the classroom where kids can be creative but where there's also a structure. And it's given me confidence because of the great results we've had. Not just the contest. I've seen kids really develop their own confidence-and that gives me confidence.

Program evaluations have repeatedly found that teachers value this support and look to Scenarios staff as a resource throughout the school year.

\footnotetext{
${ }^{9}$ This rule comes from the New York Writers' Coalition, which helped Scenarios deepen its understanding of and approach to journaling and narrative writing in curricula.
} 


\section{REAL DEAL Film Program}

I'd always wanted to become an actress, and I was always a good writer... . Everyone was telling me I should be a director, but I was like, "No, I don't want to do that." Once I understood what the director does, I thought, "This is easy, I can do that."

- Tiauna Clark, 2008 contest winner, now a film student at the School of Visual Arts in New York City

At the completion of the REAL DEAL curriculum, students develop a story or a script (maximum of ten pages) often drawing directly from their journal writing, which they then have the option of submitting to the Scenarios REAL DEAL writing contest. ${ }^{10}$ The stories and scripts students submit respond to the curriculum. For example, the masculinity curriculum generated poignant entries about homophobia, pressures to prove one's manhood by joining a gang, and intimate partner violence, among other themes. As the curriculum widened to address gender, power, and relationships, scripts tackled such topics as stigma related to being overweight, sexual abuse of boys, and trafficking of teenage girls.

As noted earlier, the possibility of shooting a film with a Hollywood director induces many students to seriously engage in their writing, including those who rarely show up to class or complete assignments. Anthony Nocerino, who teaches the curriculum to New York City students in Harlem and Brooklyn, commented:
[The scriptwriting contest] attracts all kinds of girls: Goth girls, girls who were doing their own thing. One of the girls I'll never forget wrote a screenplayshe was a cutter, she cut herself, but she was really attracted to writing and was a great writer. She loved the films, wanted to be a part of it. It was such a great outlet for her.

The scriptwriting contest culminates in the development, production, and distribution of a new batch of student-written REAL DEAL films. The entire process is coordinated by Rob York, Director of Media Production and Distribution at Scenarios.

\section{Selecting Winning Scripts}

Typically, close to 500 students submit a script or story; some scripts are coauthored by two or more students. With each contest cycle, readers are struck by the authentic nature of the stories. As past contest winner Tiara Bennett says:

With some adults, it's like they just want to know about my life, and I'm not really feeling that. That's a big part of what makes Scenarios-it's genuine. The stories that you're getting from these teenagers are genuine. . . That's why everything comes together.

Scenarios conducts outreach to maintain an active list of about 1,000 volunteers across the country - teachers, young people, professionals, and others-who each read 10 scripts and evaluate them online according to the established rubric, adding constructive comments. The original batch of submissions is winnowed down to 20 semifinalists for each region, which are then sent to a second tier of online read-

10 Individual educators across the country teach the Scenarios curriculum and encourage their students to write stories. However, the writing contest is organized specifically for partnering school districts and students in these districts are the ones who may submit their work to the contest. Teachers and students are informed in advance of the criteria by which their entries will be judged and are apprised that authors' names will be deleted from scripts prior to review. 


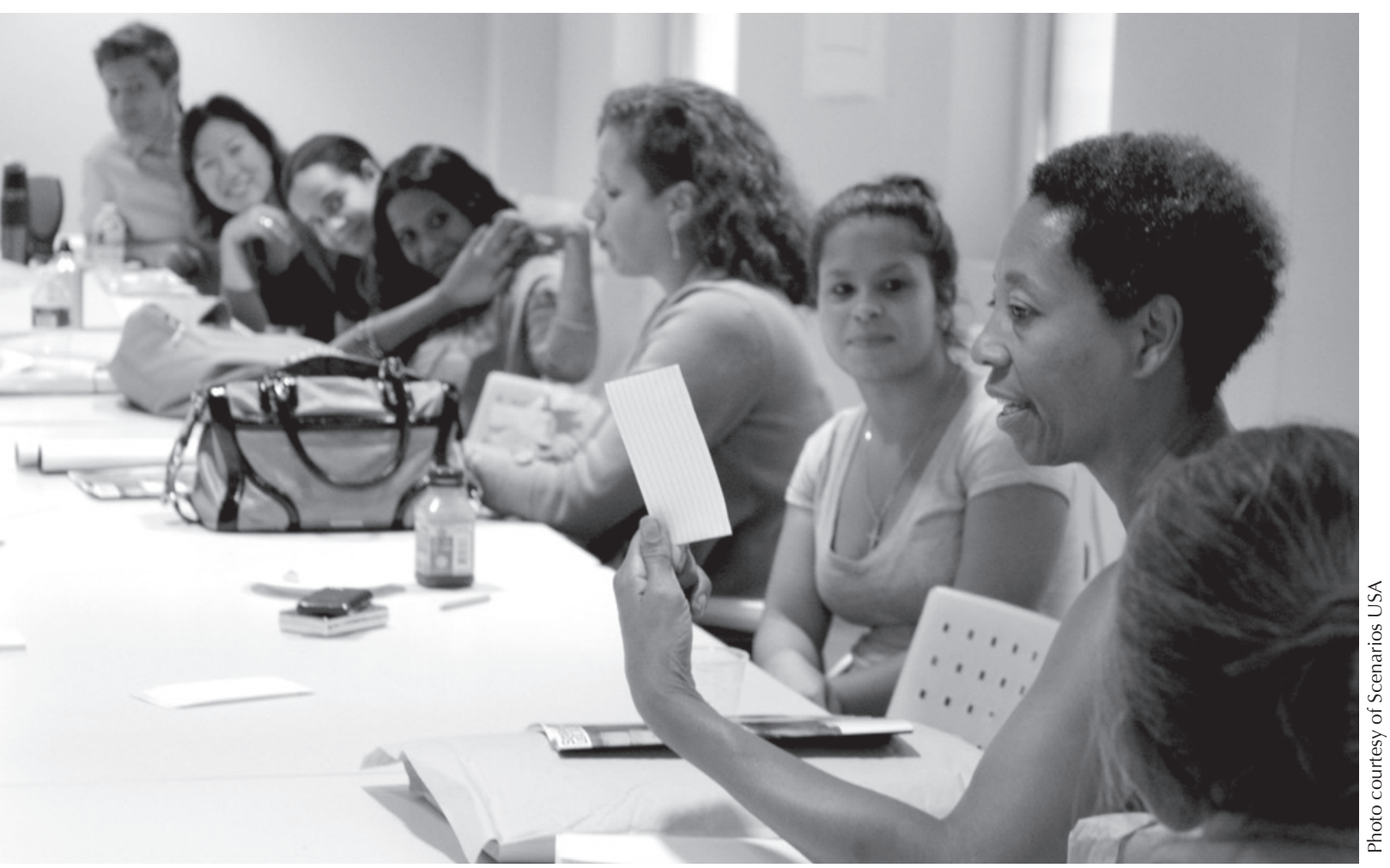

Selecting the winning scripts is a consensus process. School officials, scholars, and young people have an equal say. Scenarios staff facilitate but do not participate.

ers. This process ends with about 5 finalist scripts for each region, which are sent to the Final Selection Committee.

The Final Selection Committee is generally comprised of 16 individuals: the directors who will be shooting the films; past contest winners and other young people; school district representatives; activists; and those with expertise in youth development, gender-based violence, and other relevant topics. The committee discusses the scripts, with younger participants weighing in heavily about the authenticity and relevance of each. Winning scripts are chosen by a process of consensus, which entails going around the room again and again until everyone is comfortable with a decision. The process can take an entire day. Even winning scripts need to be developed further before they are ready for filming, and committee members also provide suggestions for that process.
Scenarios staff facilitate the meeting but do not participate. As a result, the individuals and agencies represented on the committee take ownership of the decisions and Scenarios strengthens its alliances with constituencies critical to its work.

\section{Script Development}

The raw scripts often contain scenes that would be difficult to shoot and have multiple plotlines. To develop them into final form, Scenarios pairs each winning student-writer with a director. Each director works with the writer to flesh out and refine the scripts from a story perspective, taking into account budget constraints and feedback from the Selection Committee and Scenarios staff. To manage the balance of power between the adult director and the student, Rob ensures that directors grasp the importance of respecting young peo- 
ple's opinions and are aware that young people are also busy with commitments at home and school.

Scenarios staff also help refine themes and ensure that the films will provoke reflection and avoid stereotyping. For example, one script included a scene with a group of boys in which one is asked, "Why isn't Quiana your girl?" The boy explains that because Quiana had sex with him, she no longer commands the respect that a girlfriend would have, adding, "Everyone knows you can't turn a ho into a housewife." In the original script, the scene ended with this remark, but Scenarios staff felt strongly that a further comment was needed to make the audience reflect on the language people use casually to bring one another down. In the revised script, another boy speaks up, drawing attention to the double standard implicit in the comment about Quiana, and encouraging viewers to reflect on the issue.

Finally, the script is reviewed by young people, a film professional, and teachers and officials at the local school district. On several occasions, this step has generated controversy. When this happens, Scenarios and the local stakeholders with which it has already built strong relationships have been able to support the students in advocating for their voice and their work. (See When Young Writers Face Opposition, page 26.)

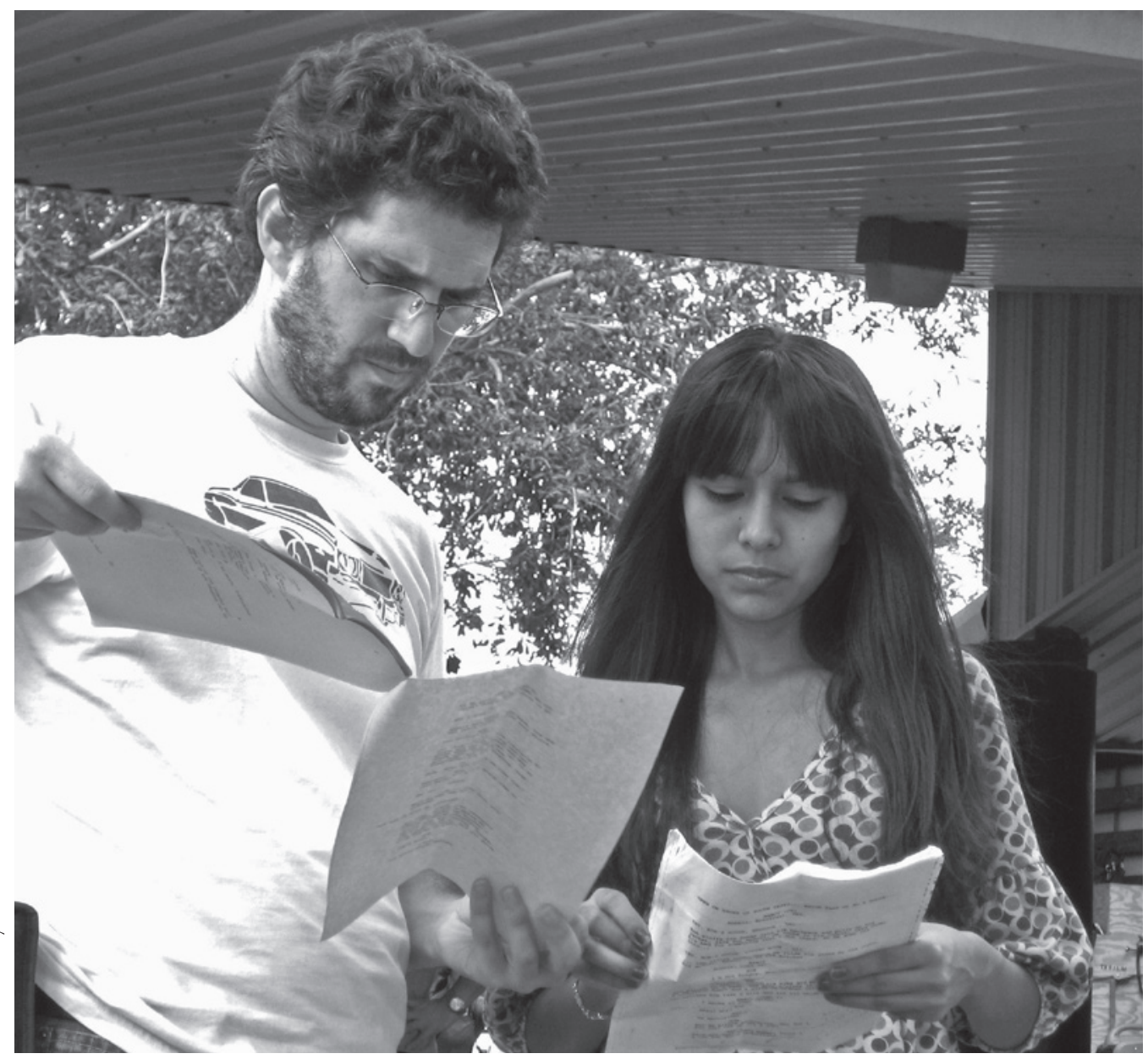

Mariella Zavala was 14 when she won the Texas contest, with a story about intimate partner violence. Director Joshua Marston worked with Mariella to turn her story into the film Bitter Memories. 


\section{Production}

Films are shot on location in the students' schools and communities. The goal is to make films that are authentic and high quality yet inexpensive to produce. Scenarios invests a great deal of effort in making young people's films look and sound real, from the dialogue, to the music, costumes, and set design. Young people on the set-writer(s), actors, and on-set interns - are quick to point out if a particular choice (a set of a young person's room, how a teenager wears a backpack) fails to reflect prevailing youth culture. Gina Prince Bythewood, who directed the 2006 film Reflections, recalls her response on first being handed the script written by 17 -yearold Keyana Ray of Maywood, Illinois:

It just felt so real. It was written by a high school girl but she seemed to have a real grasp of story. The characters were interesting; it just felt really authentic. This program, using real directors and having the films cowritten by actual kids . . . I think it gives an authenticity that kids identify with.

Especially for young people of color from urban communities, these films are a rare opportunity to see their lives and neighborhoods portrayed with accuracy and nuance.

\section{Inexpensive but High Quality}

Given the increasing availability of inexpensive video cameras as well as YouTube and other free dissemination platforms, amateur moviemaking has become exponentially more feasible since Scenarios shot its first film in 1999. Scenarios staff know that they must produce a high-quality product in order to market, distribute, and earn income from their films. As Maura explains, "We hear from students that they take seriously seeing themselves reflected in high-quality media. These stories matter, and it's worth making it look hot."

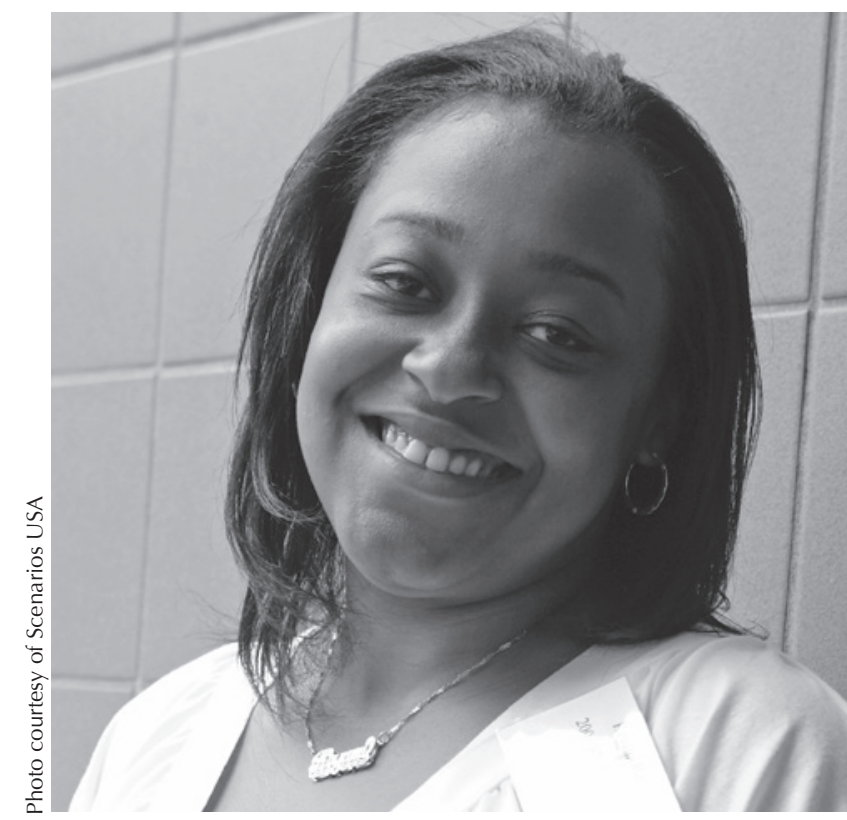

Keyana Ray based her story, about HIV and power imbalances in male-female relationships, partly on the memory of an aunt who had died of AIDS.

High-quality film production and editing, however, can be exorbitant. Scenarios keeps costs remarkably low in various ways. First, the directors - and these are famous, in-demand individuals-work for free. The rest of the media professionals on the crew and editing team donate their time or charge a reduced rate. As Maura says, "People at these companies believe in our mission, and it's thanks to them that the films look and sound fantastic."11 All of the actors are volunteers, and much of the work "on set" is carried out by young interns, many of whom were semifinalists in the writing contest. For young interns, working on set builds technical skills (for example, with equipment and logistics), deepens immersion in the topic the film will address, and increases understanding of the power of film to raise social awareness.

Local communities also routinely pitch in. (The fire department in one Texas town offered Scenarios free use of its ladder truck

\footnotetext{
11 Several top-level companies (including Deluxe Labs and Panavision, both of which work on Hollywood feature films) donate their equipment and talent to Scenarios for production and post-production.
} 
to shoot a particularly challenging scene.) Such community participation does more than reduce cost, it also builds a sense of collective endeavor in lifting up young people's voices. As Kristen reflects:

Film is by nature a collaborative and collective project. It's sort of like throwing a big party or potluck. Everybody in the community has to come together to make the project work. That's what the films are like when we're making them-the school district contributes something, the police block traffic, grandmothers bring tamales, people contribute their houses. It just creates relationships in support of young people telling these stories and their truth, whatever truth that is. It forces the community to face the reality of teenagers' lives.

As a result of this collective volunteer effort, the average cost of producing and editing a 15-20 minute film is approximately $\$ 50,000$ - one-fourth the normal cost to produce a film of the same length and quality. Scenarios raises this money from various donors, including individuals who respond to the organization's "I Am a Producer" campaigns. Scenarios staff are also on the set to provide technical backup.
Past contest winner Tiauna Clark puts it more pithily: "People are expecting some low-budget film, and I'm like, hello? It's on Showtime."

\section{Screening and Distribution}

Once the films are edited (at one of several major post-production houses that do the work pro bono), Scenarios organizes a national premiere in New York City, attended by the press, a large audience, and the winners of the writing contest and their teachers and directors. The writers are trained in public speaking and are prepared to talk about their films and themselves at the premiere and in other public venues, often including television and radio talk shows. During the course of each year, more than 20 million viewers watch a Scenarios film. The films are broadcast on major television networks, viewed online, and-often with the screenwriters present-shown at film festivals and community screenings.

As the last stage in the cycle, the films circle back to the Education Program, where they form the basis for the next curriculum. The films, along with lesson plans, are also sold as DVDs and serve as an ongoing source of income for the organization's programs.

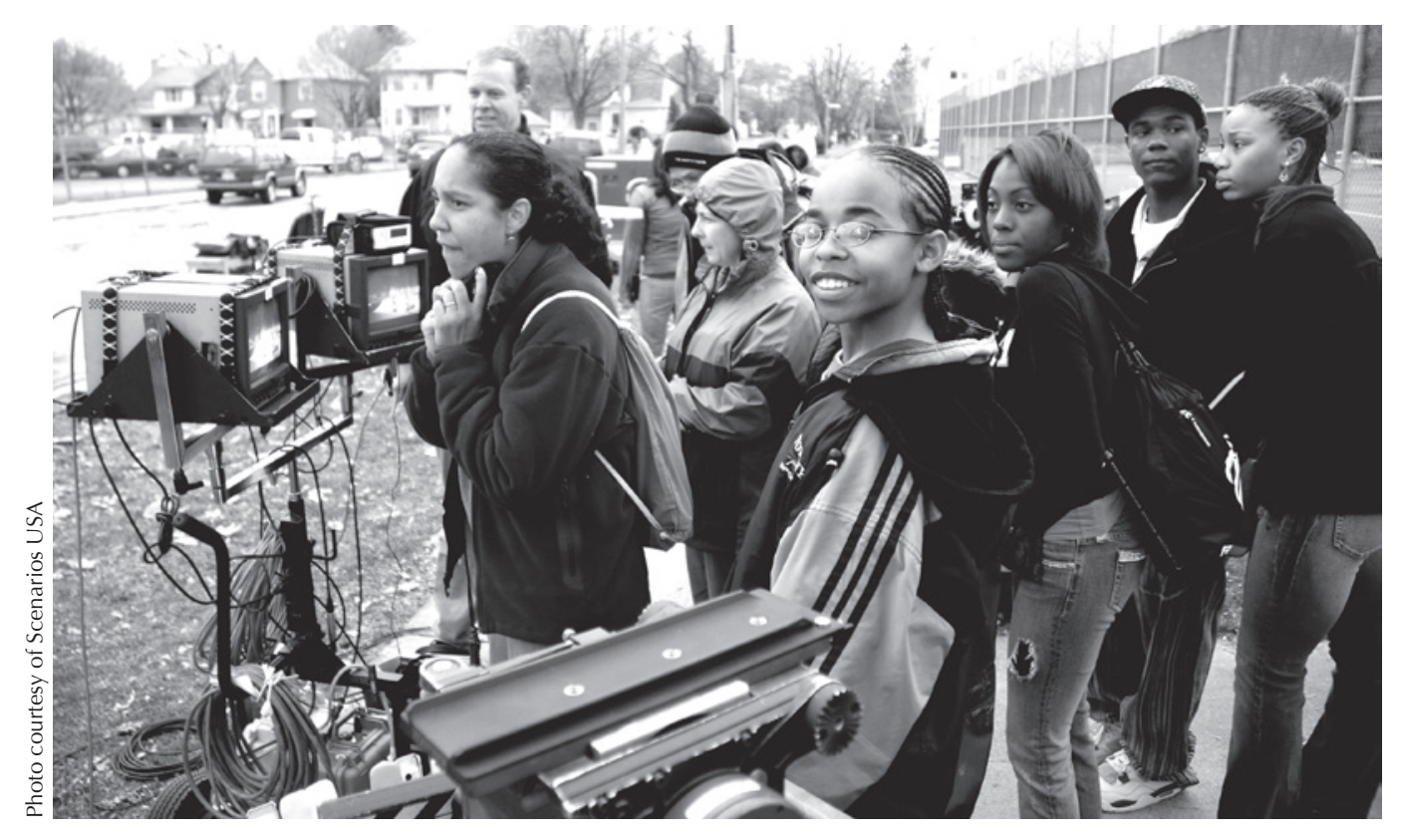


Fostering Youth

Engagement and

Leadership

Scenarios invests significant effort and resources in amplifying young people's voices and building their leadership capacity. Sometimes by having a separate staff person coordinating youth activities, and more recently by integrating youth engagement across its work, Scenarios builds deep and lasting bonds with a key cohort of the young people they reach. These investments also give Scenarios access to a network of youth allies who are equipped to disseminate the organization's message and provide feedback on its model.

While the most intensive mentoring takes place with contest winners, other young people also come into the Scenarios orbit-contest finalists and semifinalists, participants in occasional community projects Scenarios sponsors, and others whose interests lead them to remain engaged. Key strategies beyond the curriculum for investing in young people's engagement and leadership include:

- Involving young people during the script development and filming;

- Connecting young people with internships, scholarships, and career development advice, through both adult-youth and youth-youth mentoring;

- Amplifying young people's voices through blogs, social media campaigns, and other online communications strategies;

- Organizing a photography course and exhibit for lesbian, gay, bisexual, transgender, and questioning (LGBTQ) youth in New York City;

- Collaborating with youth organizers, activists, and youth-serving organizations from around the country;
- Hosting a biannual leadership conference for past and current contest winners, REAL DEAL writers, on-set interns, and others;

- Seeking and obtaining structured formal feedback from young people on Scenarios' programs.

Through their participation in evaluation activities, young people like Michael, Jermaine, and Magen have identified the areas in which they have grown because of their experience with Scenarios:

- Self-esteem and self-efficacy for speaking in public;

- Social capital, attained through relationships with adult mentors and an extended peer network;

- Access to educational and employment opportunities, including formal internships and scholarships, as well as career development advice, recommendation letters, and help writing college applications and applying for jobs;

- Interpersonal communication (with peers, partners, parents, and other adults) and public speaking skills, with a focus on telling one's story and speaking about taboo topics;

- Practical skills and experiences, particularly for careers in media, the arts, and social or nonprofit work, and the confidence to set and achieve educational and career goals;

- General social and cultural horizons (for many alumni, attending their film's premiere in New York City was the first time they ever boarded a plane or left their state). 


\section{Success Stories}

Michael Torres, a 2009 writing contest finalist, was invited to participate in the on-set internship program and was later invited to participate in the Scenarios USA/Writers Guild of America East (WGAE) Foundation Mentorship Project. Michael recalls:

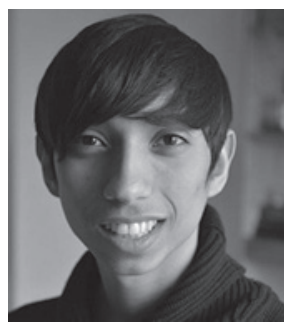

When the contest was over I thought I was finished with screenwriting, but the internship was the next level for me. I'm completing a feature-length script, and my mentor from WGAE helped me apply to Tisch School of the Arts at New York University, which I was accepted to for Dramatic Writing. It wouldn't be the same without Scenarios USA. I wouldn't be here at NYU, I wouldn't be studying playwriting, and I wouldn't have gotten all these great experiences.

When Jermaine Wall won the writing contest, along with a group of coauthor friends, Maura would drive him home after a long day on the film set. He showed her the public housing projects where he had grown up, which were slated for demoli-


tion. Over time, she and Jermaine had many conversations. "He wanted to go into marketing so he could make money, but he didn't have the heart for it. Connecting with Scenarios changed the trajectory of Jermaine's life. Inspired by his involvement with the organization, he went on to become a sexual health educator and then a social worker. The young people he works with today face similar challenges to the ones he faced as a teenager. Jermaine comments:

Scenarios helped me realize as a social worker that the impossible is possible with the population that we work with, because it's sometimes so tough for them to have any type of success.

Jermaine still uses Scenarios materials and strategies in his efforts to engage the young people he serves.

Magen Rodriguez was 14 when she became a New York City semifinalist in the REAL DEAL contest and an on-set intern. Later that year, she attended the organization's fundraising gala. A Scenarios staff member prepared the young attendees, and Magen recalls the experience:



I'm really short. I'm five feet tall, and I was really young compared to these billionaire professionals. But I wasn't afraid. I spoke to so many people. Scenarios empowered me to do that; they made me feel confident.

Magen went on to win a scholarship to college and worked for a while on the Scenarios staff. She is now in graduate school. 


\section{When Young Writers Face Opposition}

Not all opportunities to develop youth leadership are planned. Scenarios curricula get students thinking and writing about such issues as gender-based violence, power arrangements, abortion, and sexualitytopics that make some adults in the community uncomfortable. Because Scenarios has a policy of engaging with communities beyond the confines of the school, some scripts have come under fire even before the film is shot.

\section{Scenarios curricula get students writ-} ing about such issues as gender-based violence, power arrangements, abortion, and sexuality-topics that make some adults uncomfortable.

On a few occasions Scenarios has had to step in to defend the integrity of young people's language. Students tend to include authentic speech in their scripts, and in some cases school administrators have objected. For example, the script that won the 2002 contest in Florida followed three teenage boys as they dealt with the responsibilities of fatherhood, peer pressure, passion, and STDs. On reviewing a copy of the script, the local superintendent of schools instructed his assistant to rewrite its dialogue in "the King's English," removing all the slang and expressions that made the script sound real to young people. Scenarios, joined by the school principal and the film's director, insisted on keeping the original dialogue, and eventually the school district acquiesced.

When a small group of vocal individuals in Mission, Texas, mobilized to block the production of Toothpaste, a script written by local students that featured a scene where girls bought condoms, Scenarios staff flew to Texas to support the writers.
They enlisted the help of local allies, including drama teacher Gilbert Zepeda. They also organized a training to help the four girls who had coauthored the script mount a campaign to defend it. At a community board meeting held in a church, both the contest winners and their parents-many of whom only spoke Spanish and had never attended a public or school meeting - argued passionately and persuasively for the film. As Kristen reflects:

Toothpaste really became a class issue. The film was written predominantly by students from recently arrived Mexican families versus more established white and Mexican families in the community. The young people who wrote the film came from lower-income neighborhoods, and the film showed a glimpse into their lives. It became evident at one of the meetings that [opponents] weren't just upset about the condoms, they were upset that a film was being made about Mission for national distribution that showed lower-income neighborhoods, and worried that the impression people would have of Mission was "low-income" and "condoms."

The parents who got up to speak at the church in support of the film were from lower-income, more recently arrived families, and many were the parents of the kids who were actually making the film. And then there were the city residents and churchgoers on the other side.

\section{Gilbert recalls:}

The kids were so level-headed. The girls were very smart and mature about how they handled things. They wanted to present their stand and their message and make sure their film was going to be shown. It was kids doing it, which made the people who were opposing look like bullies. There was no reason the kids shouldn't be going out and telling people not to get pregnant, not to have unprotected sex. 
In the end, three-quarters of the attendees offered their support. The resulting film - which featured girls buying and handling condoms - enjoyed wide community support and was used in the local schools, allowing condoms to be discussed inside many classrooms for the first time. But the struggle to get Toothpaste made was also an important moment in Scenarios' realization that meaningful community engagement-and supporting students to negotiate community power dynamics — played a pivotal role in their work.

Gilbert adds, "After that battle was fought, other schools started opening up and having the program in their district. So it actually helped the program grow."

The staff also learned about the importance of community engagement through some hard lessons. In 2002, Scenarios partnered with Planned Parenthood Federation of America to sponsor a nationwide writing contest focused on sexual health topics. One of the winning scripts featured a teenage girl struggling about whether to disclose to her friends and soccer teammates that she is a lesbian. The film was to be shot on school grounds in Orange County, California, but local school officials and principals opposed the project and refused Scenarios access to their athletic fields. Scenarios realized they lacked a network of local stakeholders to defend the project.

These disparate experiences demonstrated the transformative impact that Scenarios could have on challenging local power structures by insisting on young people's right to tell their stories. But they also convinced Scenarios of the importance of community participation and of directly equipping young people with the means to defend their films and champion the issues they support. Another outcome was the formation of a Speakers Bureau, a core group of young people who could advocate for their films and for the organization's work.

\section{Assessing Outcomes}

It's about the way I look at things. I look at things differently now.

$$
\begin{array}{r}
\text { - High school student from } \\
\text { Cleveland, Ohio }
\end{array}
$$

\section{Methods}

Rigorous evaluation is a challenge for complex programs like Scenarios. First, the Scenarios program has multiple and fluid inputs. It reaches young people through more than one channel; it contributes to outcomes that are determined by multiple factors; each new curriculum contains different content (although over the past six years, the curricula have emphasized similar concepts and pedagogy); the organization engages teachers and other key people in various ways; and teachers use the curriculum and films flexibly. Second, the outcomes that Scenarios' curricula seek to achieve can be difficult to measure. As Kristen reflects:

We wanted to evaluate how much we are helping young people to develop their ability to think critically and to strengthen their sense of identity.

In addition to the methodological challenges, Scenarios has not had the resources for rigorous, quasi-experimental outcome studies. Nevertheless, over the years the organization has worked with a range of partners to design and implement periodic evaluations and learning exercises. The 2002 evaluation conducted with Planned Parenthood used traditional qualitative research methods - interviews and surveysto evaluate impact on students and teachers. The 2004 script analysis conducted by researchers from the Columbia University School of Public Health involved content analysis to capture trends and gaps in the vast data mineable from student scripts. ${ }^{12}$

Subsequent evaluations-most pivotally, a 2009 evaluation of the "What's the REAL DEAL about Masculinity?" curriculum-have come closer to capturing the 
kinds of changes in critical thinking and sense of identity that Scenarios had previously struggled to measure. The 2009 evaluation drew on several methods: ethnographic approaches including participant observation and conversation analysis in classes prior to and during teaching of the Scenarios curriculum; ${ }^{13}$ content analysis of student scripts from the masculinity curriculum cycle compared with earlier cycles that did not explicitly address gender norms; and in-depth interviews with teachers and students. Conversation analysis was a particularly exciting tool for Scenarios. As Kristen reflects:

A conversation analyst could listen to how the conversation in class flowed, and then we could actually distill down the elements of what critical thinking looked like and sounded like. [We learned that] a conversation where critical thinking is happening is a conversation where comments build on one another and where people are using self-reflection and applying that to the conversation. A conversation analyst can measure that.

Yet another learning exercise took place in 2011-12. After completing the curriculum, students were asked to complete a brief Reflection Survey, asking about the impact of the curriculum on their: self-efficacy in speaking up about selected salient issues (e.g., power, gender norms, bullying); sense of engagement and connectedness at school (e.g., school participation); and attitudes about gender norms and school safety. There were also two open-ended reflection questions. A separate survey was given to teachers before and after they attended the training workshop where they learned about the curriculum.

Finally, in-depth interviews were carried out in developing this case study. ${ }^{14}$

Although the evaluations and learning exercises were not quasi-experimental trials, and most have not included control arms, the findings across region and timeand from both students and teachers-have been remarkably consistent. The following section reviews key findings.

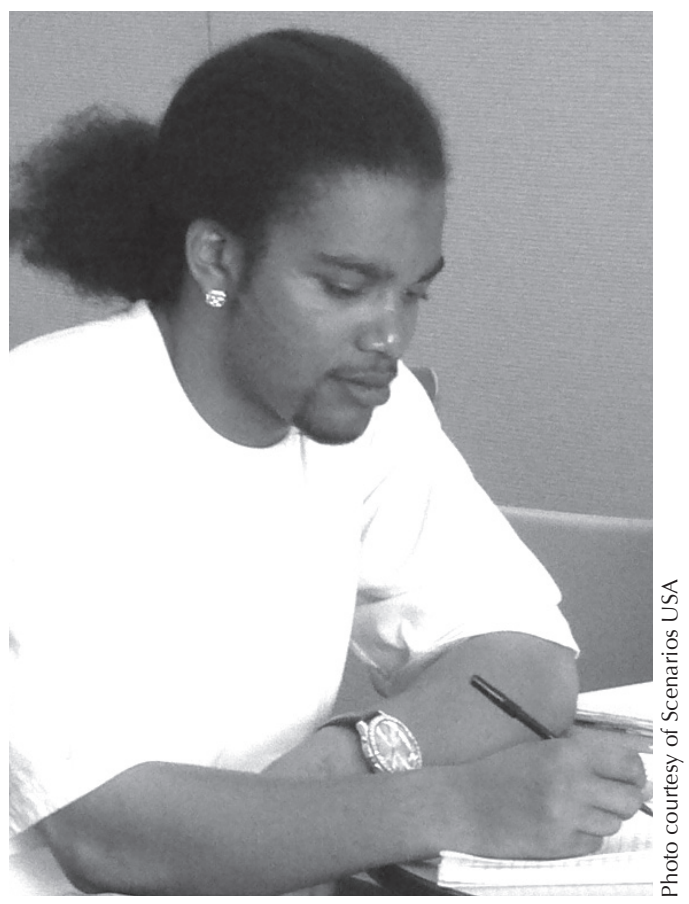

When Scenarios introduced the masculinity curriculum, staff noted that the scripts students submitted began to question gender norms in a far more meaningful way than previously. Researchers who conducted a blind content analysis of scripts across years confirmed this finding.

\footnotetext{
${ }^{12}$ Key results from the 2002 and 2004 evaluations are discussed in Scenarios' Education Program, page 10.]

${ }^{13}$ The ethnographic research design also benefited from technical consultation with ethnographer France Winddance Twine of the University of California, Santa Barbara.

14 Today, evaluation is a routine element of Scenarios' work. With support from external researchers, each year Scenarios collects and analyzes pre- and post-survey responses from students, teachers, and Final Selection Committee members, often supplemented by content analyses of student reflection letters and scripts or oneon-one interviews with teachers and other key stakeholders.
} 


\section{Results}

\section{Confidence and Skill as Writers: Using Writing to Explore Emotional Conflict}

Keeping journals and writing scripts deepened students' confidence in their ability to express themselves in written and verbal form, and objectively improved their writing skills (Pederson et al. 2002; El-Hinnawy 2009). A frequent observation was summed up by one teacher who reported, "I've seen disengaged students come alive as writers and get excited about working hard and revising their work." Writing also provided an important outlet for youth to process difficult experiences.

I feel like I can express myself. Sometimes certain kids, or myself, we walk in here with something bad that happened to us or just something we want to talk about, and sometimes it's not good to tell people. So the journal allows us to express ourselves freely, without judgment.

\section{- Katherine Blanco,} New York City

Writing is a very therapeutic experience for me. It helped me come to terms with a lot of things in terms of relationships, especially with my dad. It's not just what's happening in the world, it's how it relates it to your life.

$$
\begin{array}{r}
\text {-Michael Torres, } \\
\text { New York City }
\end{array}
$$

\section{Critical Thinking and Dialogue Skills}

I think [the curriculum] gave my conversations a bit more meaning. I actually started to analyze my life as if it were a piece of literature.

\section{- High school student}

For a number of years, teachers had been anecdotally reporting that the Scenarios REAL DEAL curricula were extremely effective at getting students to talk to each other and think critically. As part of the
2009 evaluation, Naela El-Hinnawy, an external ethnographic researcher, carried out classroom observations and interviews with teachers and students to assess these effects, among others. To gather baseline data, the researcher first observed a subset of classes in the days prior to starting the masculinity curriculum, using an instrument for coding observations. The quality of dialogue and critical analysis was measured for the classroom as a whole, not individually. The results confirmed the teachers' reports, as classroom discussions transformed when following the REAL DEAL curriculum. Key findings are reported, as follows.

Compared with baseline observations, students were much more likely to employ dialogue skills. Overall, the tone of discussions was more respectful; students engaged in active listening and follow-up questioning, referring back to classmates' comments, such that individual comments added relevance, depth, and complexity to the structure of the conversation. Moreover, derogatory comments and behavior toward one another or the teacher that had been expressed during the baseline control classes ceased during the Scenarios curriculum. This does not mean classroom talk became dry and stale. As 16-year-old Gabrielle Rodriguez explains:

When we have the discussions, like oh my God. You have the different opinions and it's like, No, this way! No, that way! And you get to hear different opinions - what this person thinks and what everybody else thinks-against your own opinion.

The observational study also documented that the curriculum led to an increase in students' attempts to make connections between experiences and information, and to analyze or explain why peopleincluding the students themselves-maintain certain beliefs, feelings, or behaviors. El-Hinnawy attributed this result to both 
the discourse-based nature of the Scenarios lesson plan and the fact that the topic (masculinity) was amenable to meaningful and open conversation.

\section{Attitudes about Gender, Diversity, and Bullying}

Findings suggest that the "What's the REAL DEAL About Masculinity?" curriculum challenged students' (and teachers') attitudes about male gender. Girls were more likely than boys to challenge prevailing norms (El-Hinnawy 2009). These findings were confirmed in subsequent evaluations of the 2009-10 and 2011-12 curricula, as well as in interviews with teachers and with current and former students. As an example, teacher Gilbert Zepeda reports on the effect of the film Bitter Memories (written by Mariella Zavala, a student at his Texas school), about gender-based violence:

\section{It brought out a lot of controversy among the students. Does a boyfriend have the right to tell his girlfriend how to dress, to make demands of the girl? Should the girl go back to the boy? Down here, that happens a lot. The girls have to be submissive to the boys. But when they saw that film, it empow- ered a lot of the girls to say, "No, it's not right for that to happen."}

In Cleveland, students responded to the question of whether it is ever appropriate for a boy to be vulnerable:

Manny: No!

\section{Ricky: No!!}

Aisha: Yes! When they break up with a girlfriend.

Brandon: No. I think of someone being masculine as someone who holds it in.

Keisha: One time, one of my guy friends was telling me about something that made him sad. He started to cry and he put his head on my shoulder and I just hugged him. It made me feel so special for him to let me see him cry.
Felice: No, I don't like all that whimpering. That's what a child does, not a man. I don't wanna hear all that.

Rudy: Well, it's okay to cry when no one can see you.

In another Cleveland class, students considered the gendered meaning of a boy's refusing sex. Whereas a boy who has multiple sexual conquests is a "player," the boy who has multiple partners as a result of advances made by girls was considered a "bopper" (traditionally a pejorative term referring to a female who offers oral sex to multiple male partners). In the students' discussion, the feminizing implications for a boy to be viewed as passive or submissive surfaced. The teacher allowed the students to explore this contradiction:

Teacher: [So] is it okay for a boy to bop?

Leon: No.

Juan: Malcolm's a bopper.

Malcolm: I ain't no bopper!

Ronette: If you go to this girl and this girl and this girl like what's-your-name, then you a bopper. But all those girls come to him. What he supposed to do. ... Beat them on the head with a stick?

Malcolm: Thank you. I love both of $y^{\prime}$ all to death.

Tommy: How is that a good thing when a man gets called a bopper?

For many students, these conversations offered the first opportunity to question the norms that governed their social world. In this way, critical thinking outcomes and gender norms outcomes are inextricably interlinked. Kimberly Roman, a 15-yearold student at Hostos Lincoln Academy in the Bronx, illustrates this point cogently:

It's eye-opening. When you get into it, you start to see things differently. Your perspectives on people change. You may have never known that your best friend may be homophobic, or your best friend maybe thinks that boys are better than girls. You start to see ideas 
that maybe would never have come up in conversation.

Similarly, in the 2011-12 survey, 52 percent of students reported that after completing the Scenarios curriculum they felt more confident talking about power and gender norms. Fully 79 percent reported that they had become "more thoughtful about sexist and homophobic language." Their new attitudes are translating into different social behaviors. In New York City, teacher Anthony Nocerino commented on the influence of the masculinity curriculum:

I had boys who were hyper-masculine, saying, "This is gay, he's so gay." By the end of [the curriculum], they were more tolerant. It definitely had an effect on them.

In South Texas, a group of students who completed the masculinity curriculum went on to establish a gay-straight alliance at their school. Responses from the most recent surveys indicate that the "Gender, Power, and Relationships" curriculum inspired students to stand up for peers who were being bullied, and to feel closer to their classmates. As 17-year-old Edward said, "I definitely tell my friends they shouldn't be mean to gay people, people who like the same sex, because it's not fair. Like, you wouldn't want to get bullied."

\section{School Connectedness}

It made me want to come to school and it made me want to be productive. It was Scenarios and it was masculinity.

- High school student from Cleveland, Ohio

Even in the earliest years of the program, teachers had been reporting that the REAL DEAL curricula increased students' enthusiasm and sense of connectedness with regard to school. The 2009 evaluation confirmed this finding (Pederson et al. 2002; El-Hinnawy 2009; Scenarios USA 2010). As Katherine Blanco of Hostos attests:
This class is the best part of my day... You feel free. You can be yourself, and whatever you say here, stays here-nobody's gonna go outside and be like, "Oh, you know what she said in class?" You're learning, and you're working, but you're having fun the whole time.

The 2002 evaluation carried out with Planned Parenthood documented that students' engagement was also giving teachers much-needed energy and inspiration. In the words of Miami high school teacher Tim Flay, who was interviewed as part of the 2002 evaluation:

I saw all the kids putting in the effort. And to hear so many people say, "Wow, these kids are really good," that made me proud.... This was something that put fuel in my tank... I thought, "Oh good, I did something right."

New York City teacher Rebecca Fabiano commented as well on students' engagement and its relationship to the inquirybased approach:

Scenarios USA challenged our students to think... They were not passive recipients of information, but active in their own education. We saw students who rarely come to class come regularly. We saw students who didn't speak up in class share their views and opinions.

Many have echoed Flay's and Fabiano's sentiments, reporting that the curriculum has improved their teaching, brought them closer to the teenagers in their classes, and unlocked even their most reticent students' capacities.

Another part of being connected at school is feeling safe, a rare feeling for many young people marginalized by their sexual orientation, language or learning challenges, or a physical disability. One teacher, reporting that discussions triggered by a Scenarios film about homophobia (Man in the Mirror) changed the at- 
mosphere in the classroom, explained, "I think it allowed me to truly create a safe environment in my classroom in which students were, at times, able to be themselves and share honestly."

Again in the 2011-12 evaluation, students reported that they perceived themselves as more likely to finish high school and go to college as a result of the curriculum. Achieving this enthusiasm and engagement is far from trivial. A sense of connectedness is the single most important variable for keeping young people at risk from dropping out of school (Barber and Olsen 1997; Rosenfeld, Richman, and Bowen 1998; Battin-Pearson et al. 2000; Klem and Connell 2004). Indeed, the Centers for Disease Control identifies promoting school connectedness as a strategy for improving adolescent sexual health outcomes.

\section{An Integrated Theory of Change}

Scenarios did not start out with a strategy for addressing gender and power, critical thinking skills, and school connectedness. The organization developed its theory of change inductively, through experience and through evaluations of distinct curricula and separate outcomes. As Ernestine explains:

[Sexual health] remains the ultimate goal, but what has changed is the realization that good sex education is good education: the literacy, the connectedness, the critical thinking skills. Now we can be more explicit about those, and I think the sexual health goals are more implicit.
Despite the methodological limitations discussed above, these ten years of findings suggest a fresh and exciting logic model, which, put simply, looks something like the illustration below.

This model has parallels with those few sexuality education programs that have gone beyond reporting behavior change to demonstrate health outcomes. This conceptual model, with implications for academic outcomes as well, may be of particular value for schoolbased programs' designing and evaluating interventions.

\begin{tabular}{|c|c|c|c|c|}
\hline $\begin{array}{l}\text { Teaching } \\
\text { activity }\end{array}$ & $\begin{array}{l}\text { Cognitive } \\
\text { and affective } \\
\text { processes }\end{array}$ & $\begin{array}{l}\text { Learning } \\
\text { objective/ } \\
\text { Attitudinal } \\
\text { change }\end{array}$ & $\begin{array}{l}\text { Protective } \\
\text { factor }\end{array}$ & $\begin{array}{l}\text { Health } \\
\text { outcome }\end{array}$ \\
\hline $\begin{array}{l}\text { Narrative } \\
\text { writing about } \\
\text { how gender } \\
\text { and power } \\
\text { operate in } \\
\text { their lives }\end{array}$ & $\begin{array}{l}\text { Meaningful } \\
\text { personal } \\
\text { reflection } \\
\text { and critical } \\
\text { thinking } \\
\text { about } \\
\text { gender and } \\
\text { power }\end{array}$ & $\begin{array}{l}\text { Adopting } \\
\text { egalitarian } \\
\text { attitudes } \\
\text { about } \\
\text { gender and } \\
\text { power } \\
\text { Increase } \\
\text { school } \\
\text { connected- } \\
\text { ness }\end{array}$ & $\begin{array}{l}\text { Less vulnera- } \\
\text { bility to STIs, } \\
\text { unintended } \\
\text { pregnancy, } \\
\text { and intimate } \\
\text { partner } \\
\text { violence } \\
\text { Reduce } \\
\text { school } \\
\text { dropout }\end{array}$ & $\begin{array}{l}\text { Lower rates } \\
\text { of STIs, } \\
\text { unintended } \\
\text { pregnancy, } \\
\text { and intimate } \\
\text { partner } \\
\text { violence }\end{array}$ \\
\hline
\end{tabular}




\section{Ongoing Challenges}

Any organization as ambitious and dynamically evolving as Scenarios will face its share of challenges. Despite its impressive accomplishments, the organization faces a number of persistent programmatic and institutional challenges.

\section{Obstacles for Teachers}

While some teachers are longtime champions of Scenarios, various obstacles constrain teacher participation. First, although Scenarios does not charge for its training, budget cuts in schools mean that fewer teachers have leave to attend the Scenarios training workshops; in some districts, these cuts have resulted in hundreds of teachers losing their jobs altogether. Scenarios has partially addressed this problem by hiring on-the-ground staff in focus regions and by establishing specific criteria before agreeing to partner with a new school district.

Second, school performance (and funding) are increasingly based on students' scores on standardized tests. In the current education policy environment, these scores trump higher-order thinking skills and participatory learning approaches, and sexuality education is a relatively low priority. Scenarios has compensated in part by working within a language arts and social studies rubric, rather than within health education. Ensuring that the curricula comply with state education standards has also helped.

Third, teaching the REAL DEAL curriculum is personally demanding. Difficult personal issues may surface for students during the lessons, and many students have few (or no) supportive adults in their lives. Moreover, teachers have their own personal experiences to confront. For example, the fatherhood lesson in the masculinity curriculum has led to the most meaningful connections between teachers and students, especially when teachers opened up about their own father or lack of a father (El-Hinnawy 2009), but this process required internal struggle for some teachers. As Ernestine notes:
When I'd say, "We're going to write about fathers now," in almost every training workshop, a male teacher has said, "This is hard for me." They would throw their pen down on the table. When I showed them Bitter Memories (a 2007 film that features an abusive father), they cried.

Staff constantly seek ways to support teachers without being intrusive-offering to observe classes, organizing webinars, maintaining the Curriculum Corner area of Scenarios' website and contributing to its Educators' Blog, and facilitating online teacher-to-teacher dialogue aimed at addressing common challenges.

\section{Losing the Contest}

For many students, especially reluctant learners, simply finishing a piece of writing is a huge accomplishment. Consolidating a semester's writing into a story or script and submitting it to a contest requires significant effort and a measure of confidence. Only a tiny proportion of entrants can win and the rest are likely to experience some degree of disappointment. The challenge is to prevent that disappointment from eroding a young person's self-esteem. To validate students' efforts, Scenarios delivers the Selection Committee's comments to everyone who submits a script. The curriculum also offers teachers alternative ways to help students publish or perform their work (such as staging scenes from students' scripts or organizing student readings), and many teachers adopt these ideas. The organization also engages interested students as on-set interns and sometimes as actors. As Alexander Leslie of the Cleveland Rape Crisis Center points out:

The Scenarios program is really based in resiliency. [They] only pick one winner, but you still have your voice. And you still have a chance to develop a caring relationship with an adult-either the teachers or an adult working on the film. And that makes a big difference. 


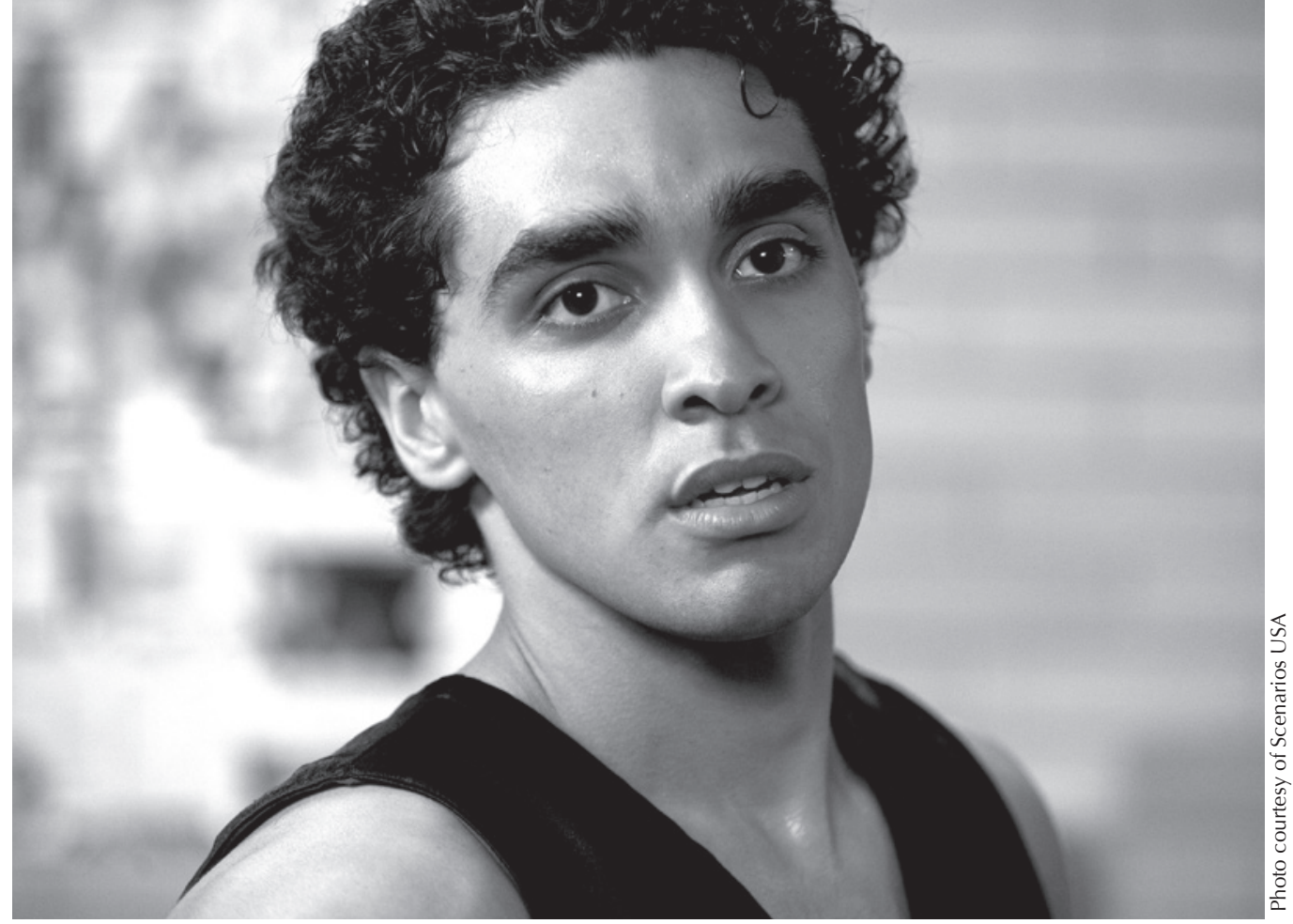

The film Man in the Mirror (starring E.J. Bonilla, above), about homophobia, made some schools uncomfortable. But after a series of adolescent suicides by students suffering homophobic bullying at schools across the country, educators were desperate for ways to generate meaningful reflection about the issue. Man in the Mirror has helped fill that need ... but Scenarios knows that dealing with opposition will remain part of its work as it continues to share adolescents' life stories.

Most recently, Scenarios has been strengthening its use of social media and other online engagement strategies as another way of cultivating positive relationships with as many young people as possible in a sustainable way, fostering all young people's potential as change agents and increasing the number of possible connection points they have with Scenarios-outside of and within the classroom.

\section{Limited Geographic Reach}

There are undoubtedly thousands of talented young writers across the country who would love to submit a script to Scenarios, but the current model involves establishing deeper roots in a small number of areas. Scenarios did run a second, successful nationwide contest in 2006, in cooperation with the Black Entertainment Television (BET) network.

The curricula and films are distributed to every US state and internationally, and the films are incorporated into a number of other widely used curricula. Scenarios is also disseminating materials through webinars, online lesson plans, social media, and alliances with like-minded organizations. For sponsoring contests and testing new curricula, however, they stick to regions where they are invited and supported by the school district, a local funding base, and other local stakeholders. There is not a plan at this time for going to scale with the same quality and anticipated outcomes.

\section{Political Opposition}

As long as Scenarios curricula enable teachers and students to question harmful but well-entrenched norms, the organization and student-writers will encounter some opposition. Mediating such conflicts and building common ground requires significant effort and has led Scenarios toward an outreach model that prioritizes engagement in a few key regions, based on willingness among local stakeholders (both funders and school district officials) to support the program. 


\section{Convincing Policymakers}

Like most sex education programs, Scenarios is under pressure to demonstrate the degree to which its model demonstrates results. On one hand, Scenarios' achievements have underscored the limitations of public health approaches to sex education. On the other hand, sexual health outcomes are not the exclusive goal, and conventional frameworks for sex education programs do not fit the Scenarios approach.

The organization's integrated model is a complex one: fostering leadership, advocacy, and self-expression, especially among students in marginalized communities, to strengthen their academic achievement, promote civic engagement, and support them in becoming engaged citizens and healthy individuals. Unfortunately, policymakers often mistake an intersectional approach as being unfocused. Convincing policymakers can be difficult in a funding landscape that still marks success narrowly: that is, a statistically significant proportion of young people reporting change in a single behavior (even using a survey approach known to elicit inauthentic responses).

Certainly, some donors are betting on the integrated approach that Scenarios is pioneering. For example, Rocio Cordoba, program officer for Sexuality, Reproductive Health, and Rights at the Ford Foundation, argues that the field needs programs like Scenarios, precisely " . . because it presents the reality of young people ... navigating their sexual health and rights within a much broader and more complex context." Currently, Scenarios draws its support primarily from numerous foundations, municipal governments, and individual donors, as well as through sales of its films and curricula. The staff hopes that resources will be allocated in the future for rigorously assessing the impact of their programs-on a range of health, social, and educational outcomes.

\section{Conclusion}

As Scenarios has evolved, its basic beliefs-in honoring and sharing young people's voices and stories, in critical reflection, and in gender justice-have driven the political and pedagogical evolution of the organization. These commitments shine through in all of the organization's work, inspiring teachers, film directors, school administrators, parents, and most crucially, young people themselves.

The approach has made Scenarios a vanguard in the field of sexuality education. Scenarios' experience has shed light on a fresh and integrated way to promote school connectedness, academic performance, and community engagement. For Scenarios, these goals crystallized over the years, but they were also implicit in Maura and Kristen's original vision. If programs like Scenarios are to thrive, thinking and resources need to be allocated toward developing innovative, rigorous evaluation models that can capture the interconnected effects of such work.

In the meantime, the ongoing work keeps Scenarios on the cutting edge of contemporary media and policy debates. For example, the $2011 \mathrm{film}$ Man in the Mirror focused on homophobic bullying.

A few months later, after a series of LGBTQ young people across the country committed suicide in response to homophobic bullying in their schools, the issue dominated the US news media. As Maura comments:

\section{[Homophobic bullying and violence] is so common. And yet it only comes to the surface because the news media says it should? No. That's why these sto- ries matter. Young people are already telling us what is really happening. We just have to take the time to listen.}

Scenarios has staked its work on that idea, and particularly on listening to low-income youth of color, who are so often sidelined and stereotyped by the media and other institutions. 
Reflecting on her 15 years of work with Scenarios, Maura perpetually returns to the boy from Laredo, Texas, who challenged her on that bumpy school bus about why anyone would want to know what he thinks. That day, Maura returned his gaze. "You do have a story to tell," she replied. "It's an important story, and your participation matters."

"That still sits with me," Maura adds. "No kid should ever think that he doesn't have something to say."

\section{Lessons Learned}

Narrative writing, storytelling, and journaling are powerful techniques for encouraging personal reflection and attitude change. Research shows the direct benefits of narrative writing on adolescent well-being. For young people navigating adolescence, often in a climate of racial and/or gender discrimination, the chance to express themselves in a safe way in writing can be a conduit to surfacing and resolving inner conflicts, organizing their thoughts, and engaging in school. For educators, treating journals and stories as fictional is important to reduce potential concerns about confidentiality.

Gender and power issues must be at the heart of a curriculum. Keeping gender-sensitive messages at the periphery of a curriculum is not effective. Scenarios found that, despite their years of efforts to foster meaningful reflection about gender norms, teachers and students did not dive into the issue until it became the explicit theme (with the curricula on masculinity and on gender, power, and relationships).

Better approaches (and investments) are needed to evaluate programs that address a range of underlying protective factors. In the past, the conventional wisdom has been that sex education should focus on such proximate protective factors as knowledge and refusal skills and aim at a single behavior. More creative approaches to evaluation are needed to measure the impact of programs like Scenarios on a range of outcomes, including:

- Sexual health outcomes, such as condom use and STI rates;

- Social outcomes, such as intimate partner violence and homophobic bullying;

- Educational outcomes, such as school connectedness, attendance, academic performance, and dropout rates.

Such evaluation must seek to assess the benefits of such inputs as narrative writing, critical thinking activities, and reflection about gender issues.

Young people respond deeply to the stories told by other youth. But rendering those stories permanent through film amplifies the impact and enables changes in social norms, institutions, and communities. 


\section{References}

Barber, B.K. and J.A. Olsen. 1997. "Socialization in context: Connection, regulation, and autonomy in the family, school, and neighborhood, and with peers," Journal of Adolescent Research 12(2): 287-315.

Battin-Pearson, S., M.D. Newcomb, R.D. Abbott, et al. 2000. "Predictors of early high school dropout: A test of five theories," Journal of Educational Psychology 92(3): 568-582.

Campbell, R.S. and J.W. Pennebaker. 2003. "The secret life of pronouns: Flexibility in writing style and physical health," Psychological Science 14(1): 60-65.

Casemore, B., K. Sandlos, and J. Gilbert. 2011. "On taking an interpretive risk in sex education." Teachers College Record. http://www.tcrecord. org. Accessed 5 July 2013.

Centers for Disease Control and Prevention (CDC). 2009. "School connectedness: Strategies for increasing protective factors among youth." Atlanta, GA: US Dept. of Health and Human Services.

El-Hinnawy, N. 2009. "Miss? What's manhood? Report on a social-studies based sex education program." Scenarios USA. Unpublished report.

Haberland, N. 2013. "What happens when programs emphasize gender? A review of the evaluation research." Presentation at Expert Group Meeting on Adolescent Sexual and Reproductive Health Programming. 4-6 February. Manhasset, NY.

Klem, A.M. and J.P. Connell. 2004. "Relationships matter: Linking teacher support to student engagement and achievement," Journal of School Health 74(7): 262-273.
Muñoz-Laboy, M., et al. 2004. "Between drama and tragedy: Dealing with fear on media sex education for teens?" Unpublished.

Pederson, S., et al. 2002. "Scenarios USA: What's the real deal? A summary of the evaluation of the 2001 Scenarios USA national and Miami-Dade County scriptwriting contests and film projects." Unpublished.

Pennebaker, J.W. 1997. "Writing about emotional experiences as a therapeutic process," Psychological Science 8(3): 162-166.

Pennebaker, J.W. and J.D. Seagal. 1999. "Forming a story: The health benefits of narrative," Journal of Clinical Psychology 55(10): 1234-1254.

Pettersson, T. 2003. "Basic values and civic education: A comparative analysis of adolescent orientations towards gender equality and good citizenship." World Values Survey. <http:// www.worldvaluessurvey.org/wvs/articles/ folder_published/publication_504>.

Rogow, D. and N. Haberland. 2005. "Sexuality and relationships education: Toward a social studies approach," Sex Education 5(4): 333-344.

Rosenfeld L.B., J.M. Richman, and G.L. Bowen. 1998. "Low social support among at-risk adolescents," Social Work in Education 20(4): 245-260.

Sandlos, K. 2010. "On the aesthetic difficulties of research on sex education: Toward a methodology of affect," Sex Education 10(3): 299-308.

Scenarios USA. 2010. "Evaluation of 2009-10 REAL DEAL Program." Unpublished.

\section{About the Authors}

Rafael Mazin (Introduction) is Senior Advisor for HIV/STI Prevention at the Pan American Health Organization (PAHO).

Andrea Lynch (Case Study) is a Program Officer at the Foundation for a Just Society.

\section{Acknowledgments}

We wish to thank the staff of Scenarios USA and the teachers and young people who cooperated in preparing this edition of $Q / C / Q$.

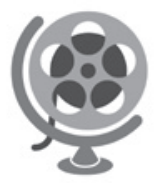

SCEN ARIOS
To order films or curricula, or for further information, contact: Scenarios USA

80 Hanson Place \#305

Brooklyn, NY 11217

Phone: 718-230-5125

Email: info@scenariosusa.org

http://www.scenariosusa.org 


\section{Resumen en Español}

El campo de la educación sexual a veces ha descuidado la profunda influencia que el contexto social de los adolescentes-más predominantemente, las normas de género-ejerce en la salud sexual. Sin embargo, la educación sexual demuestra ser mucho más eficaz en reducir las tasas de embarazos no deseados y de las enfermedades de transmisión sexual cuando el contenido promueve el pensamiento crítico respecto del género y el poder. Esta edición de $Q / C / Q$ presenta Scenarios, un programa que ha reinventado la educación sexual con fines de mejorar la salud sexual, la igualdad de género y la conexión que los alumnos sienten con sus maestros y la escuela.

Los currículos de Scenarios no transmiten información sobre anticoncepción, reproducción o pubertad. En cambio, alientan a los estudiantes a pensar, hablar y escribir sobre sus propias vidas. (Mantener un diario personal es una parte clave del currículo.) Hace seis años, los currículos comenzaron centrarse explícitamente en las normas de género, la dinámica del poder social y las relaciones íntimas - factores que afectan profundamente a la salud sexual. Scenarios crea nuevos currículos cada dos años, que se vinculan con estándares de aprendizaje establecidos. (También ofrece capacitación docente en ciertas regiones.)

Después de completar el currículo, los estudiantes dramatizan sus escritos y los presentan a Scenarios para un concurso de escritos. Los ganadores colaboran con un director de Hollywood para crear una breve película basada en el guión. Las películas se integran en el siguiente currículo como disparadores de debates.

Los estudios de evaluación indican que, desde que Scenarios comenzó a enfatizar los temas de género y poder, los estudiantes están cuestionando las normas convencionales relacionadas con estos problemas, en las clases y en sus guiones. Tanto los maestros como los estudiantes informan también que los currículos atraen a los alumnos más renuentes, que valoran que alguien quiera escuchar su historia. Y los maestros sienten satisfacción al fomentar las habilidades de pensamiento crítico en los estudiantes, así como su sentido de conexión con la escuela, la variable clave para retener a los estudiantes que están en riesgo de abandonar los estudios. $Q / C / Q$ nunca ha presentado un programa de los Estados Unidos, pero creemos que este estudio de caso puede generar el progreso necesario en el campo.

\section{Résumé en Français}

Le domaine de l'éducation sexuelle a parfois |négligé l'influence profonde du contexte social des adolescents - en particulier les normes de genre-sur la santé sexuelle. Pourtant, l'éducation sexuelle se révèle être beaucoup plus efficace pour réduire les grossesses non désirées et les IST lorsque les programmes mettent l'accent sur la réflexion critique sur le genre et le pouvoir. Ce numéro de $Q / C / Q$ présente le programme Scenarios, programme de création pédagogique qui réinvente l'éducation à la sexualité pour aborder les résultats de santé sexuelle, l'égalité des sexes et l'engagement de l'école.

Le programme Scenarios ne transfère pas d'informations sur la contraception, la reproduction ou la puberté. Il vise au contraire à encourager les étudiants à réfléchir, à parler et à écrire sur leur propre vie. (La tenue d'un journal est un élément clé du programme). Au cours des six dernières années, les programmes ont mis l'accent sur les normes de genre, la dynamique du pouvoir et les relations intimes-les questions mêmes qui façonnent les résultats de santé sexuelle des adolescents. L'organisation crée de nouveaux programmes liés à des normes d'apprentissage établies tous les deux ans. (Ces programmes offrent également une formation des enseignants dans des régions partenaires sélectionnées.)

Après avoir terminé le programme, les étudiants mettent en scène leur travail d'écriture et peuvent le soumettre au concours d'écriture du programme Scenarios. Les lauréats sont associés avec un réalisateur d'Hollywood qui vient du quartier du jeune auteur et crée un court-métrage basé sur le script. Les films sont ensuite intégrés dans le prochain programme pédagogique au fur et à mesure de la discussion.

Selon des études d'évaluation, depuis que le programme Scenarios a placé l'accent sur le genre et le pouvoir, les étudiants s'interrogent sur les normes conventionnelles relatives à ces questions, tant en classe que dans les textes soumis. Les enseignants et les étudiants signalent également que le programme Scenarios encourage la participation des étudiants les plus récalcitrants, qui apprécient que I'on écoute leurs histoires. Dans le même temps, les enseignants sont satisfaits de pouvoir encourager l'esprit critique des étudiants, ainsi que leur sentiment d'appartenance à l'école-la variable clé pour retenir les étudiants à risque de décrochage scolaire. Q/C/Q n'a jamais présenté de programme Américain, mais nous pensons que cette étude de cas peut entraîner des progrès plus que nécessaires dans ce domaine. 
We invite your comments on Quality/Calidad/Qualité. If you would like to be included on our mailing list, please send an e-mail to: qcq@popcouncil.org.

This issue of Q/C/Q can be downloaded at: <www.popcouncil.org/pdfs/qcq/qcq21.pdf>.

Most past editions are available online at $<$ www.popcouncil.org/qcq $>$ or by clicking on the titles below. Single or multiple print copies of past editions may be ordered by mail.

No. 1 Celebrating Mother and Child on the Fortieth Day: The Sfax Tunisia Postpartum Program, 1989. (E)

No. 2 Man/Hombre/Homme: Meeting Male Reproductive Health Care Needs in Latin America, 1990. (E,S)

No. 3 The Bangladesh Women's Health Coalition, 1991. (E)

No. 4 By and For Women: Involving Women in the Development of Reproductive Health Care Materials, 1992. (E,S)

No. 5 Gente Joven/Young People: A Dialogue on Sexuality with Adolescents in Mexico, 1993. (E,S)

No. 6 The Coletivo: A Feminist Sexuality and Health Collective in Brazil, 1995. (E,P,S)

No. 7 Doing More with Less: The Marie Stopes Clinics of Sierra Leone, 1995. (E)

No. 8 Introducing Sexuality within Family Planning: Three Positive Experiences from Latin America and the Caribbean, 1997. (E,S)

No. 9 Using COPE to Improve Quality of Care: The Experience of the Family Planning Association of Kenya, 1998. $(\mathrm{E}, \mathrm{S})$

No. 10 Alone You Are Nobody, Together We Float: The Manuela Ramos Movement, 2000. (E,S)

No. 11 From Patna to Paris: Providing Safe and Humane Abortion, 2001. (E)

No. 12 Universal Sexuality Education in Mongolia: Educating Today to Protect Tomorrow, 2002. (E)

No. 13 What about Us? Bringing Infertility into Reproductive Health Care, 2002. (E)

No. 14 "My Father Didn't Think This Way": Nigerian Boys Contemplate Gender Equality, 2003. (E,F)

No. 15 Linking Reproductive Health to Social Power: Community Health Workers in Belize and Pakistan, 2004. (E)

No. 16 Healing Wounds, Instilling Hope: The Tanzanian Partnership Against Obstetric Fistula, 2004. (E,F,Sw)

No. 17 In Our Own Hands: SWAA-Ghana Champions the Female Condom, 2006. (E)

No. 18 Living Up to Their Name: Profamilia Takes on Gender-based Violence, 2006. (E)

No. 19 And How Will You Remember Me, My Child? Redefining Fatherhood in Turkey, 2009. (E)

No. 20 When Girls' Lives Matter: Ending Forced and Early Marriage in Cameroon, 2011. (E) 
Quality/Calidad/Qualité/ 